\title{
Structural Architecture for Development of Marginal Extensional Sub-Basins in the Red Sea Active Rift Zone
}

\author{
Reda Amer ${ }^{1}$, Mohamed Sultan ${ }^{2}$, Robert Ripperdan ${ }^{1}$ John Encarnación ${ }^{1}$ \\ ${ }^{1}$ Department of Earth \& Atmospheric Sciences, Saint Louis, USA \\ ${ }^{2}$ Department of Geosciences, Western Michigan University, Kalamazoo, USA \\ Email: ramer@slu.edu
}

Received September 9, 2011; revised October 12, 2011; accepted November 15, 2011

\begin{abstract}
This paper presents a robust kinematic model that describes northern Red Sea and Gulf of Suez rifting and the development of marginal extensional half-graben sub-basins (ESB). A combination of Landsat Enhanced Thematic Mapper Plus $\left(\mathrm{ETM}^{+}\right)$and structural data was used to provide model constraints on the development of rift segments and ESB in the active rift zones. Structural analysis shows rotation and change in strike of rift-bounding faults. The model describes the northern Red Sea region as a poly-phase rift system initiated by late Oligocene (30 - $24 \mathrm{Ma}$ ) orthogonal rifting and the development of marginal ESB (now inland ESB), followed by oblique rifting and flank uplift during the early Miocene (24 - $18 \mathrm{Ma})$. The oblique rifting fragmented the rift depression into segments separated by oblique-slip accommodation within reactivated Pan-African (ca. $600 \mathrm{Ma}$ ) fracture zones, resulting in the development of antithetic faults and an en-echelon distribution of inland ESB. The current phase of rifting was instigated by the development of the Dead Sea Transform in response to increased northeasterly extension during the middle Miocene (ca. $18 \mathrm{Ma}$ ). The model explains the widening of the Red Sea rift during the last phase more than the Gulf of Suez rift by developing more antithetic faults and formation of offshore ESB, and deepening the rift depression.
\end{abstract}

Keywords: Remote Sensing; Tectonic Model; Marginal Sub-Basins; Rift Zone; Red Sea

\section{Introduction}

It is generally accepted that the Red Sea Rift was initiated during the late Oligocene and early Miocene about $30 \mathrm{Ma}[1,2]$. The rift split the Arabian Nubian Shield (ANS) into two parts, the eastern part in Arabia, and western part in east Africa (Figure 1). Several models have been proposed for the tectonic development of the Red Sea Rift. One of the earliest models predicted a terrain of horsts and grabens during widespread rifting along steep normal faults [3]. Although this model adequately accounted for modern terrain features along the margins of the Red Sea, it did not explain the shallow Moho levels beneath the continental shelves and coastal plains. Cochran and Martinez proposed a model that attributed the shallow Moho to diffuse extension in the lower crust combined with localized brittle extension in the shallow brittle crust that form half-grabens [4]. Bohannon et al. challenged the diffuse extension model on the grounds that it required unrealistic rates of extension in the lower crust, and suggested a passive rifting model where early rifting resulted from a detachment fault that extended from near the surface on the western rift shoulder to the middle crust beneath the eastern rift shoulder [5]. According to their model, lithospheric mantle beneath the detachment rose and spread by ductile lateral extension, leading to a thinned shallow crust that evolved into a seafloor spreading center. [6] Makris and Rhim suggested the Red Sea was formed by left lateral strike-slip motion along pre-existing zones of crustal weakness (i.e. the Najd Fault system and the Central African Fault Zone) in late Oligocene-early Miocene times that produced pull-apart basins off Egypt and the Sudan, followed by seafloor spreading in the central part of the Red Sea and subsequently propagating to the south [6].

The lateral change of the African plate from collision at Mediterranean and Bitlis to active subduction zones and variation in the force distribution along the subduction zones with the presence of an intra plate weakness zone represented by the Afar plume resulted in an extensional deformation belt resembling the Red Sea and Gulf of Aden rift systems [7]. The Red Sea Rift started as a continental rift but recently, isolated volcanoes were found on the floor of the axial depression in one segment in the northern Red Sea which indicates an oceanic spreading center is beginning to develop [8]. The Red Sea Rift is controlled by pre-existing structures that determined the initial geometry of the rift axis [9]. The early Red Sea Rift was segmented along strike into distinct sub-basins 


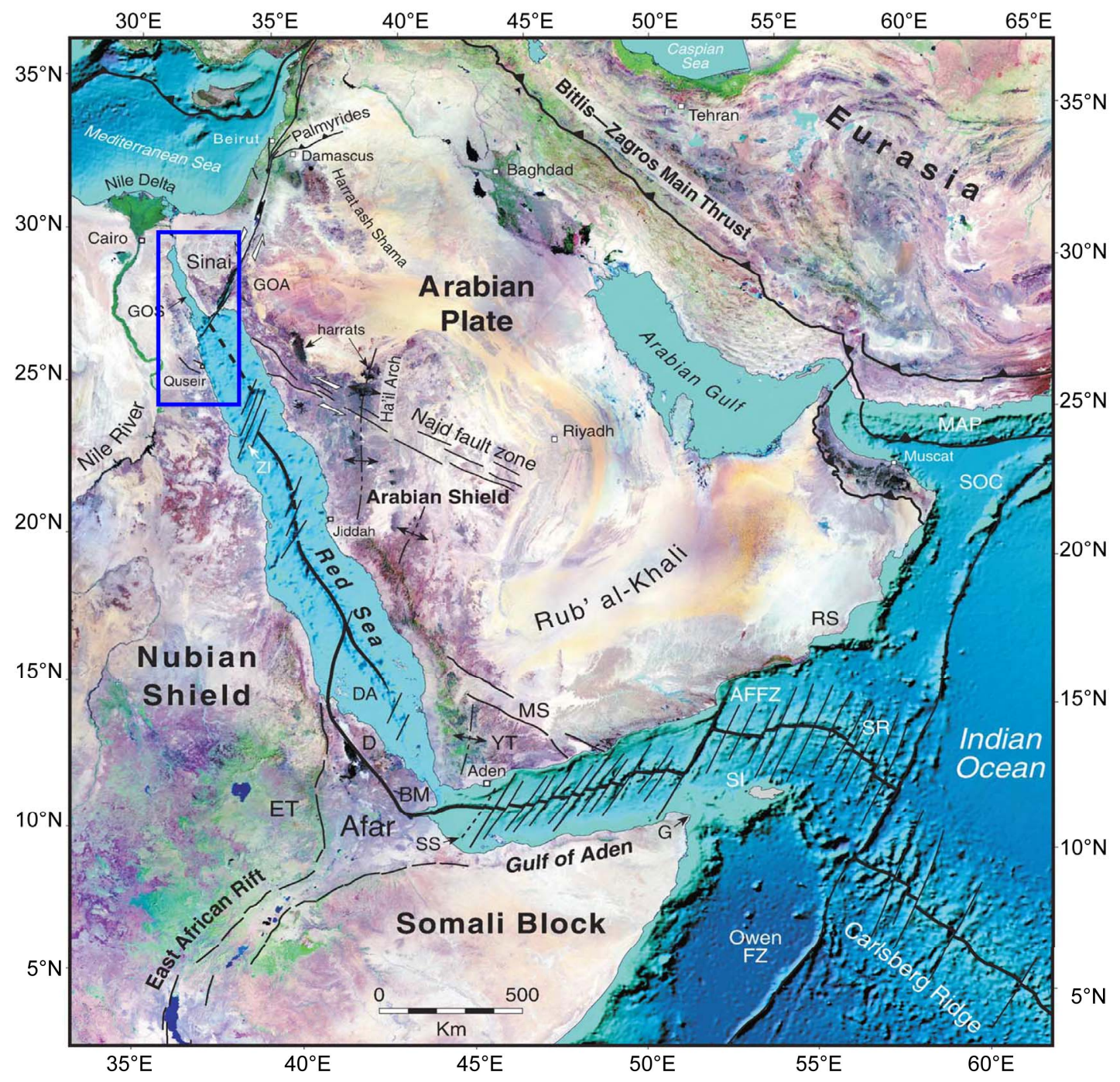

Figure 1. Landsat image shows the Arabian Nubian Shield (ANS), and Seasat-derived bathymetry of the Red Sea-Gulf of Aden rift system show major tectonic elements of the ANS, Najd fault system, the Dead Sea transform boundary, the Bitlis-Zagros convergence zone, and East African rift (modified from Bosworth, 2005). Blue rectangle delineates the location of study area (Figure 2).

with half-graben rift blocks separated by accommodation zones spaced at $40-60 \mathrm{~km}$ intervals along the rift $[8,10]$. The location and orientation of the accommodation zones were strongly influenced by pre-existing basement structures and in particular, N-S and WNW trending shear zones [11]. The border faults of the half-graben sub-basins were formed by linking the reactivated faults and fractures, producing a zigzag shape [11].

The purpose of this paper is to propose a kinematic model for the development of the marginal extensional sub-basins (ESB) in the Gulf of Suez and northwestern Red Sea active rift zones (Figure 2). The integration of remote sensing data from the Landsat Enhanced Thematic Mapper Plus $\left(\mathrm{ETM}^{+}\right)$and structural analysis provide new constraints on the role of the pre-existing structures in the development of the rift segments and the
ESB. Our study is focused on the only area in the ANS that has a sedimentary succession preserved in disconnected inland ESB.

\section{Tectonic Setting}

The orogenic evolution of the ANS can be classified into two phases: a contractional tectonic phase that lasted from about 900 - $600 \mathrm{Ma}$, followed by an extensional tectonic phase from about 595 - 575 Ma [12-14]. The contractional tectonic phase developed during the collision between east and west Gondwana and includes sutures, folds, thrust belts and strike-slip faults [15]. A second compressional tectonic event resulted in crustal shortening in the ANS which offset the east to northeast trending sutures in the northern part of the shield [15]. This occurred 


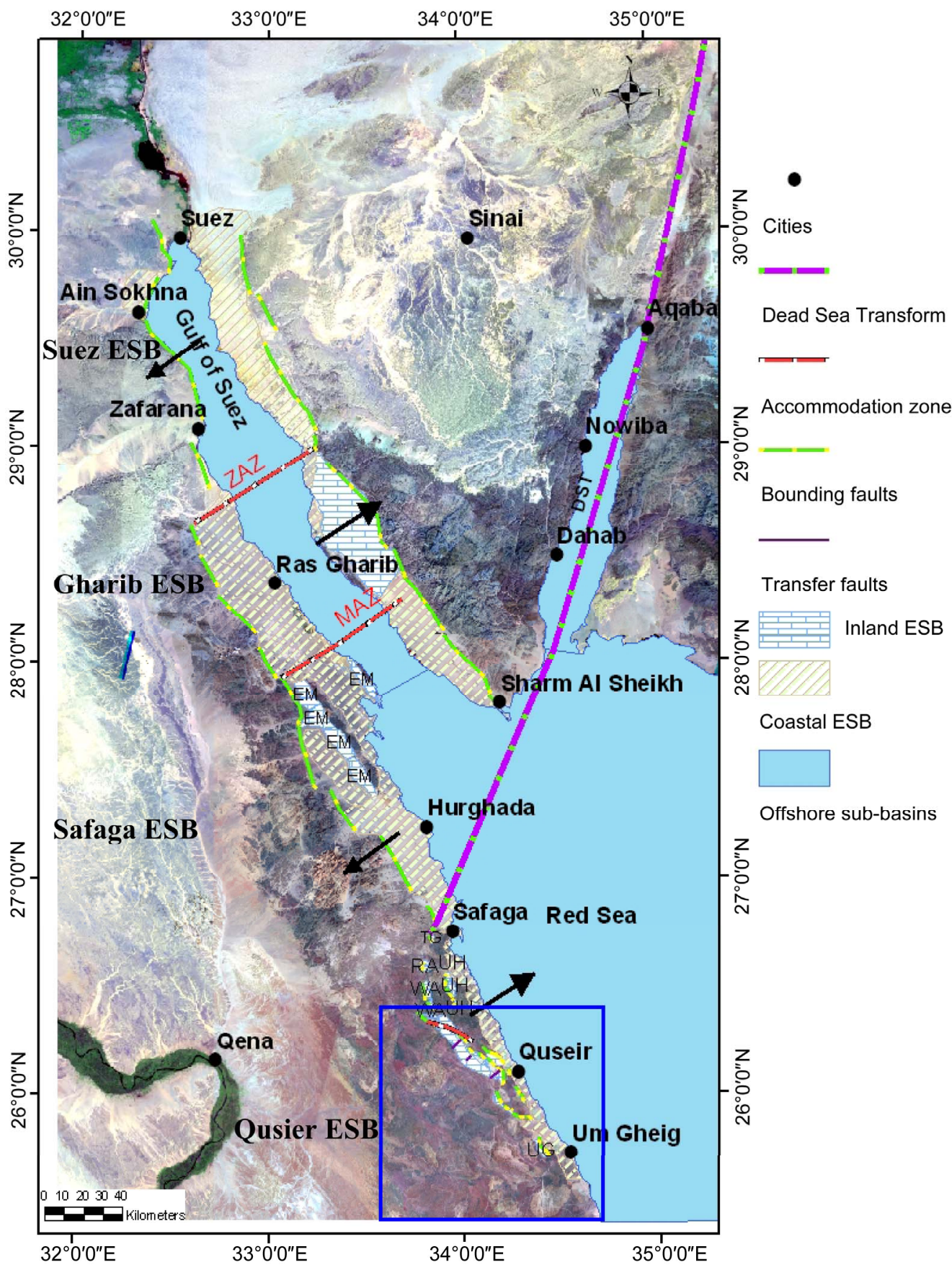

Figure 2. Landsat $\mathrm{ETM}^{+}$of the study area. Bands $(7,4,2)$ in red, green, and blue, show the distribution of rift segments (RS) in the Gulf of Suez and northwestern Red Sea. (1) Suez RS; (2) Gharib RS; (3) Safaga RS; (4) Quseir RS; (DST) Dead Sea Transform Fault (AZ) accommodation zone. Yellow circles are the main cities. Blue rectangle delineates the location of study area Figure 3.

in the late Proterozoic (670 - $610 \mathrm{Ma}$ ) during the collision of the ANS with the Nile Craton to the west and the Ar-Rayn microplate to the east, resulting in the exhumation of metamorphic core complexes such as the Meatiq, Gabal Sibai, and Hafafit domes in the Eastern Desert of Egypt and development of the NW-striking sinistral strike-slip fault Najd Fault System to accommodate the shortening [16,17].

The extensional phase of ANS evolution started in the late Proterozoic during the last stages of the Pan-African Orogen, with widespread NW-SE extension due to gravitational instability at the end of the arc-accretion phase. This caused collapse and widespread NW-SE extension represented by metamorphic core complexes (i.e. Meatiq- 
gneisses); extensional basins (i.e. molasse sediments); and large strike slip zones (i.e. Najd Fault Systems) [1820] (Figure 3). The Najd Fault Systems is a northwesttrending sinistral strike-slip system that extends over $1200 \mathrm{~km}$ and has a width of approximately $300 \mathrm{~km}$ in Saudi Arabia and the ED of Egypt [21,22] (Figure 1). The displacement of Najd Fault Systems developed the sinistral strike-slip Hamraween Shear Zone and Queih Shear Zone [23] (Figure 3). In the late Neoproterozoic $(630-590 \mathrm{Ma})$ the thickened lithospheric mantle roots of the northern ANS were delaminated and the northern
ANS uplifted to elevations of more than $3 \mathrm{~km}$, thus triggering rapid erosional unroofing and lateral extension and formation of intermontane basins (i.e. molasse sediment basins) [24].

The most recent extensional tectonic event of the ANS is the Red Sea rift which started opening in the late Oligocene to early Miocene at about $30 \mathrm{Ma}[1,2]$. The rift was associated with uplift which resulted in erosion of the sedimentary succession and exposure of the underlying basement rocks [24]. The rift reactivated the accretionary and post-accretionary Pan-African fault systems

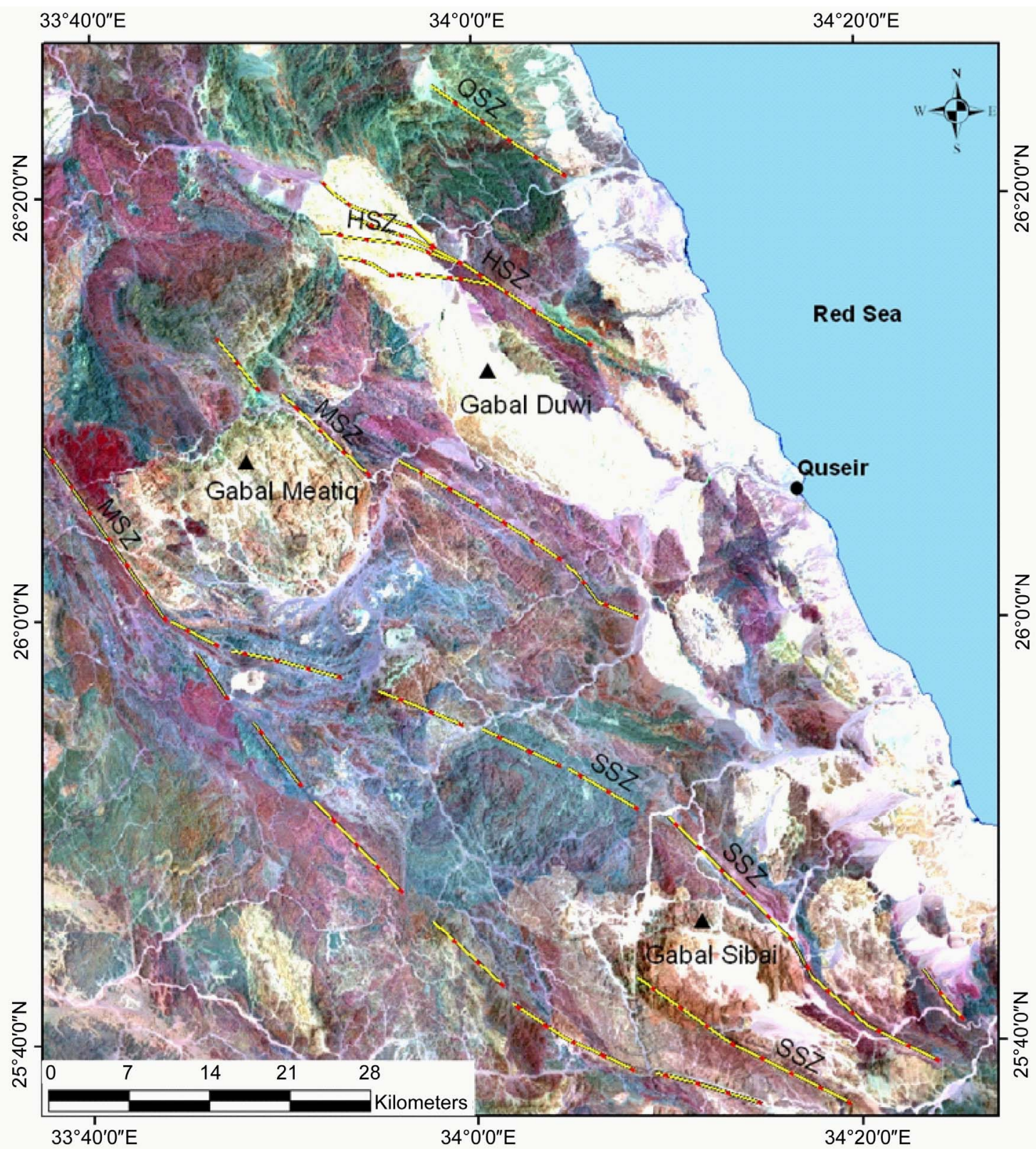

Figure 3. Landsat $\operatorname{ETM}^{+}$bands $(7,4,2)$ in red, green, and blue, show the locations of metamorphic core complexes and Najd fault system-related shear zones in the central eastern desert. Quieh Shear Zone (QSZ); Meatiq Shear Zone (MSZ); Sibai Shear Zone (SSZ). 
and led to the development of ESB in the Gulf of Suez and the northern Red Sea $[2,25,26]$. The ESB in the Eastern Desert of Egypt were formed in the late Cretaceous and nucleated as small pull-apart basins by reactivating the Najd Fault System [26,27]. Paleostress analysis of the Duwi sub-basin in the Central Eastern Desert show that it was formed compatible with principal stress directions with sub-horizontal $\sigma_{1}$ (ENE-WSW) and $\sigma_{3}$ (NNW-SSE), and a sub-vertical $\sigma_{2}$ [27] (Figure 3). Flank uplift accompanied by NE-SW extension in the Oligocene resulted from a change to a stress field with subvertical $\sigma_{1}$ [27]. A series of $\mathrm{N} 40^{\circ} \mathrm{W}$-trending normal faults associated with strike-slip faults resulted in the creation of numerous pull-apart basins along the Red Sea coastal area [28]. The thickness of the sedimentary succession preserved in the inland ESB is about $400-500 \mathrm{~m}$ and reach up to $4 \mathrm{~km}$ offshore [28].

The Dead Sea Transform Fault is one of the most tectonically active features in the ANS. It is a left lateral strike-slip fault that extends for about $1000 \mathrm{~km}$ and links a region of extension in the Red Sea to a region of contraction in the Zagros-Bitlis Convergence Zone, with slip rates that vary between 1 and $10 \mathrm{~mm} / \mathrm{yr}[29,30]$. Igneous activity and local subsidence along the Dead Sea Transform Fault suggest that the movement started in the middle Miocene (ca. $18 \mathrm{Ma}$ ) with a total displacement of approximately $105 \mathrm{~km}$ [31] (Figure 2).

\section{Lithology of the Study Area}

The study area is predominantly covered by Precambrian igneous and metamorphic terranes (basement rocks), with Phanerozoic sedimentary rocks preserved in isolated extensional sub-basins within the basement rocks and onshore and offshore of the Red Sea and Gulf of Suez (Figure 4). Basement rocks include gneisses and ophiolitic mélanges represented by serpentinites, metagabbros, and metabasalts, which were subsequently intruded by granitic rocks, overlain by the Dokhan volcanics, and covered by molàsse-type sediments [22,32-35].

The Phanerozoic sedimentary succession is classified into pre-rift, syn-rift and post-rift deposits [28,36,37] (Figure 4). The pre-rift sedimentary section is thick in the Gulf of Suez region and consists of intercalations of sandstone, shale, dolomite, and limestones ranging from Cambrian to Eocene in age (Figure 4). In the northwestern Red Sea the pre-rift succession consists of clastic and carbonate units of the late Cretaceous to Eocene. The syn-rift succession ranges from late Oligocene to Pliocene onshore and late Oligocene to Recent offshore. Some of the succession is exposed on the surface and some formations are subsurface. The succession starts with late Oligocene clastics of the Nakhil Formation, unconformably overlain by early Miocene clastics of the Ranga and carbonates of the Um Mahara Formations; these are cor- related to the Thayiba, Nukhul, and Rudeis Formations in the Gulf of Suez subsurface, respectively. This succession is overlain by middle and late Miocene deposits include intercalations of evaporites and clastics of the Abu Dabbab and Marsa Alam formations. These formations are correlated to the Kareem, Belayim, South Gharib, and Zeit in the Gulf of Suez subsurface, respectively. Onshore this succession is overlain by post-rift sediments that include undifferentiated Pliocene to Recent clastics of terrace deposits and wadi outwash deposits, and raised beaches [28,36-38].

\section{Rift Segments}

The rift system is composed of antithetically tilted rift segments delimited by the main rift bounding faults and separated by accommodation zones [25,39]. The rift segments consist of half-graben extensional sub-basins (ESB) delimited by both border faults and internal extensional faults [40], and separated by oblique-slip and strike-slip transfer faults [11]. The Gulf of Suez and northwestern Red Sea Rift consist of four rift segments from north to south: the Suez, Gharib, Safaga, and Quseir segments [11,25,41] (Figure 2). The northern Red Sea margin is formed by narrow continental shelves that are dissected by active faults, rimmed by a series of terraces stepping down to an axial depression [8].

Herein we classified the ESB into: 1) inland ESB enclosed within basement rocks and entirely bounded by faults; 2) coastal ESB that extend from inland margins with basement rocks to the shoreline and continental shelf; and 3) offshore ESB from the continental shelf to the rift depression. These ESB are separated by NW-SE internal extensional faults. The inland ESB consist of pre-rift upper Cretaceous to Eocene sedimentary successions overlain by the syn-rift late Oligocene Nakhil Formation. The coastal ESB consist of pre-rift and syn-rift successions and overlain by post-rift sediments. The offshore ESB consists of pre-rift and syn-rift deposits. The inland ESB are found in separate half-graben sub-basins between $25^{\circ}$ $-28^{\circ} \mathrm{N}$ in the northwestern Red Sea and the Gulf of Suez. The thickness of the sedimentary succession in the northwestern Red Sea and Gulf of Suez varies from 430 - 500 $\mathrm{m}$ in the inland ESB to $500-700 \mathrm{~m}$ in the coastal ESB, to as much as $4 \mathrm{~km}$ in the offshore ESB $[25,41]$.

\subsection{Structural Architecture of the Suez Rift Segment}

The Suez rift segment represents the northern tip of the Gulf of Suez and Red Sea rift system. It consists of offshore ESB that represents the Gulf of Suez rift depression and a SW-dipping coastal ESB found only on the eastern side of the Gulf of Suez, There are no inland ESB on either side of the rift (Figure 5). The rift segment is 


\begin{tabular}{|c|c|c|c|c|c|c|c|c|c|}
\hline \multicolumn{4}{|c|}{ BASEMENT CRYSTALLINE ROCKS } & \multicolumn{6}{|c|}{ SEDIMENTARY ROCKS } \\
\hline ERA & ROCK UNIT & LITHOLOGY & $\begin{array}{l}\text { RIFT } \\
\text { STAGE }\end{array}$ & ERA & PERIOD & EPOCH & FORMATION & LITHOLOGY & $\begin{array}{l}\text { RIFT } \\
\text { STAGE }\end{array}$ \\
\hline \multirow{24}{*}{ 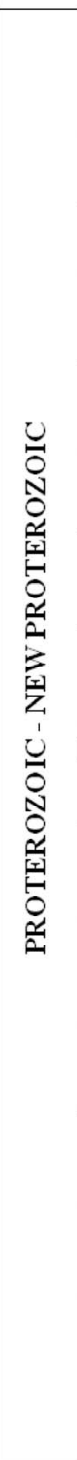 } & Trachyte plugs & & \multirow{24}{*}{ 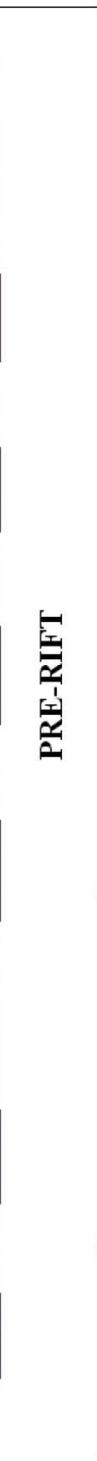 } & \multirow{11}{*}{ 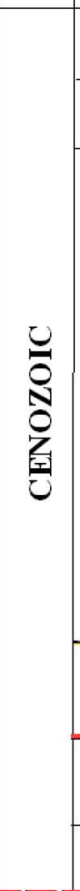 } & \multicolumn{2}{|c|}{ Pliocene - Recent } & $\begin{array}{r}\text { Wadi deposits } \\
\text { Raised beaches }\end{array}$ & & \multirow{2}{*}{$\begin{array}{r}\text { POST } \\
\text { RIFT }\end{array}$} \\
\hline & \begin{tabular}{|c|}
$\begin{array}{c}\text { Post Hammamat } \\
\text { felsite }\end{array}$ \\
\end{tabular} & & & & \multicolumn{2}{|c|}{ Pliocene } & \begin{tabular}{|l|} 
Zaafarana \\
Wardan
\end{tabular} & & \\
\hline & Dokhan volcanics & & & & \multirow{6}{*}{ 若 } & & & & \multirow{6}{*}{$\frac{\sqrt{3}}{2}$} \\
\hline & Alkaline granite & & & & & Late & 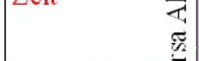 & & \\
\hline & Clacalkaline & & & & & & South Gharib & & \\
\hline & $\begin{array}{l}\text { Clacalkaline } \\
\text { grey granite }\end{array}$ & & & & & Middle & 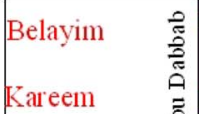 & & \\
\hline & Gabbro & & & & & \multirow[b]{2}{*}{ Early } & $\begin{array}{r}\text { Um Mahara } \\
\text { Rudcis }\end{array}$ & & \\
\hline & $\begin{array}{c}\text { Hammamat } \\
\text { sediments }\end{array}$ & & & & & & $\begin{array}{r}\text { Ranga } \\
\end{array}$ & & \\
\hline & Metasediments & & & & \multicolumn{2}{|c|}{ Oligocene } & $\begin{array}{l}\text { Nakhil } \\
\text { Thayiba Bed }\end{array}$ & & \multirow{16}{*}{ 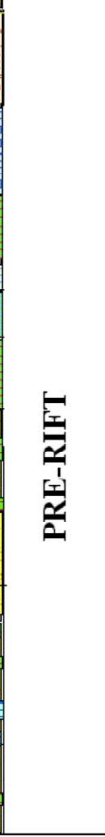 } \\
\hline & $\begin{array}{c}\text { Intermediate to acid } \\
\text { metavolcanics }\end{array}$ & & & & \multicolumn{2}{|c|}{ Eocene } & Thebes & & \\
\hline & Basic & & & & \multicolumn{2}{|c|}{ Paleocene } & Esna & & \\
\hline & & & & \multirow{8}{*}{ 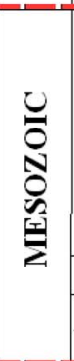 } & \multirow{6}{*}{ 萢 } & & Sudr Tarwan & & \\
\hline & Undifferentiated & 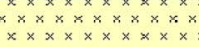 & & & & & Duwi & & \\
\hline & metavolcanics & & & & & & Matulla Dakhla & & \\
\hline & $\begin{array}{l}\text { Intrusive } \\
\text { metagabbro }\end{array}$ & & & & & Late & 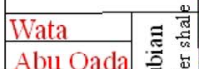 & $=z$ & \\
\hline & & & & & & & \begin{tabular}{|l|l|} 
Raha & $\bar{z}$ \\
\end{tabular} & & \\
\hline & metagabbro & $\begin{array}{l}x \times x \\
x \times x\end{array}$ & & & & Early & \multirow{2}{*}{ Malha } & & \\
\hline & \multirow{3}{*}{$\begin{array}{l}\text { Ophiolitic } \\
\text { serpentinite }\end{array}$} & & & & \multicolumn{2}{|c|}{ Jurassic } & & & \\
\hline & & & & & \multicolumn{2}{|c|}{ Iriassic } & Qiseib & & \\
\hline & & $x \times$ & & \multirow{5}{*}{ 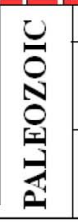 } & \multicolumn{2}{|c|}{ Permian } & \multirow{2}{*}{\begin{tabular}{|c|} 
Rod El Hamal \\
Abu Durba \\
\end{tabular}} & & \\
\hline & \multirow{2}{*}{$\begin{array}{l}\text { Leucocratic } \\
\text { gneiss }\end{array}$} & 4 & & & \multirow{2}{*}{\multicolumn{2}{|c|}{ Carboniferous }} & & & \\
\hline & & & & & & & Um Bogma & 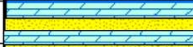 & \\
\hline & \multirow{2}{*}{$\begin{array}{l}\text { Melanocratic } \\
\text { gneiss }\end{array}$} & & & & \multirow{2}{*}{\multicolumn{2}{|c|}{ Cambrian }} & Naqus & & \\
\hline & & & & & & & Araba & & \\
\hline
\end{tabular}

Figure 4. Stratigraphic section of the Eastern Desert, northwestern Red Sea, and Gulf of Suez. Modified after Klitzch, 1987, Saied, 1990, Alsharhan, 2003. The formation names used by petroleum companies are shown in red.

bounded on both sides by faults. The western bounding fault is a NE-dipping normal fault broken into four segments with strikes of N25W, N20E, N50W, and N15W from north to south, respectively, connected by relay ramps (Figure 5). The eastern bounding normal fault dips to the SW and consists of three segments with strikes of N-S, $\mathrm{N} 30 \mathrm{~W}$, and N35W from north to south respectively, also connected by relay ramps. Slip on the eastern bounding fault segments has juxtaposed middle Miocene syn-rift coastal ESB sediments against the pre-rift Cambrian to Eocene succession. The change in strike of the bounding faults on both sides is related to translation along NE-SW dextral transfer faults. The western transfer faults divided the Galala limestone Plateau into four unequal parts from north to south: Gabal Ataqa, Gabal Akhdar, Gabal El Galala El Bahriya, and Gabal El Galala El Qibliya. The eastern and western transfer faults have similar orientation and strike-slip sense of movement, indicating they are pre-rift faults reactivated by NE-SW extension and sinistral strike-slip movement of the Dead Sea Transform. These faults were displaced left-laterally by the dip-slip bounding fault during the opening of the Gulf of Suez (Fig- 


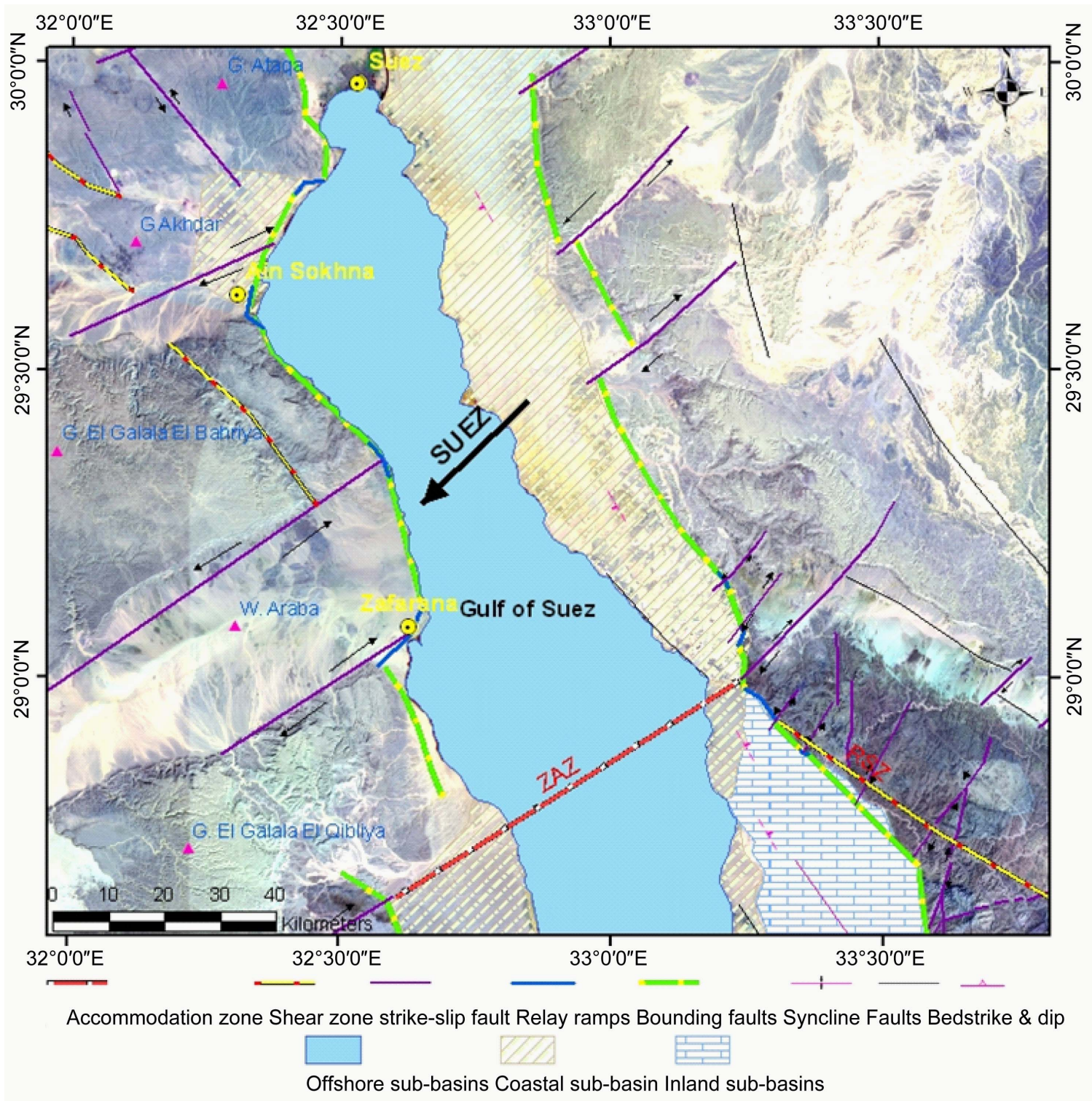

Figure 5. Landsat $\operatorname{ETM}^{+}$bands $(7,4,2)$ in red, green, and blue shows the Suez rift segments separated by Accommodation Zones (AZ); (ZAZ) Zaafarana; (RSZ) Rihba Shear Zone. Small black arrows show the strike-slip movements of transfer faults.

ure 5).

\subsection{Structural Architecture of the Gharib Rift Segments}

The Gharib rift segment represents the middle part of the Gulf of Suez Rift. It is separated from the northern Suez and the southern Safaga rift segments by the Zaafaran and Morgan accommodation zones (Figure 6). The offshore ESB in this rift segment represents the Gulf of Suez Rift depression. There is a coastal ESB on the western side of the Gharib rift segment and an inland ESB on the eastern side. Both tilt to the NE and are bounded by bounding faults. The western bounding fault has five segments with strikes of N35W, N20W, N25W, N50W, and $\mathrm{N} 25 \mathrm{~W}$, from north to south, respectively. The different segments are connected by relay-ramps. The eastern bounding fault dips to the SW and consists of three segments connected by relay-ramps. striking N45W, N-S, and N40W from north to south, respectively. The bounding fault segments have been translated by dextral strike slip movement on the NE-SW transfer faults (Figure 6). The transfer faults are found in the basement rocks on both sides of the Gulf of Suez and have similar orientation and sense of movement, indicating they are pre-rift faults that were reactivated by NE-SW extension and DST sinistral strike-slip movement. 


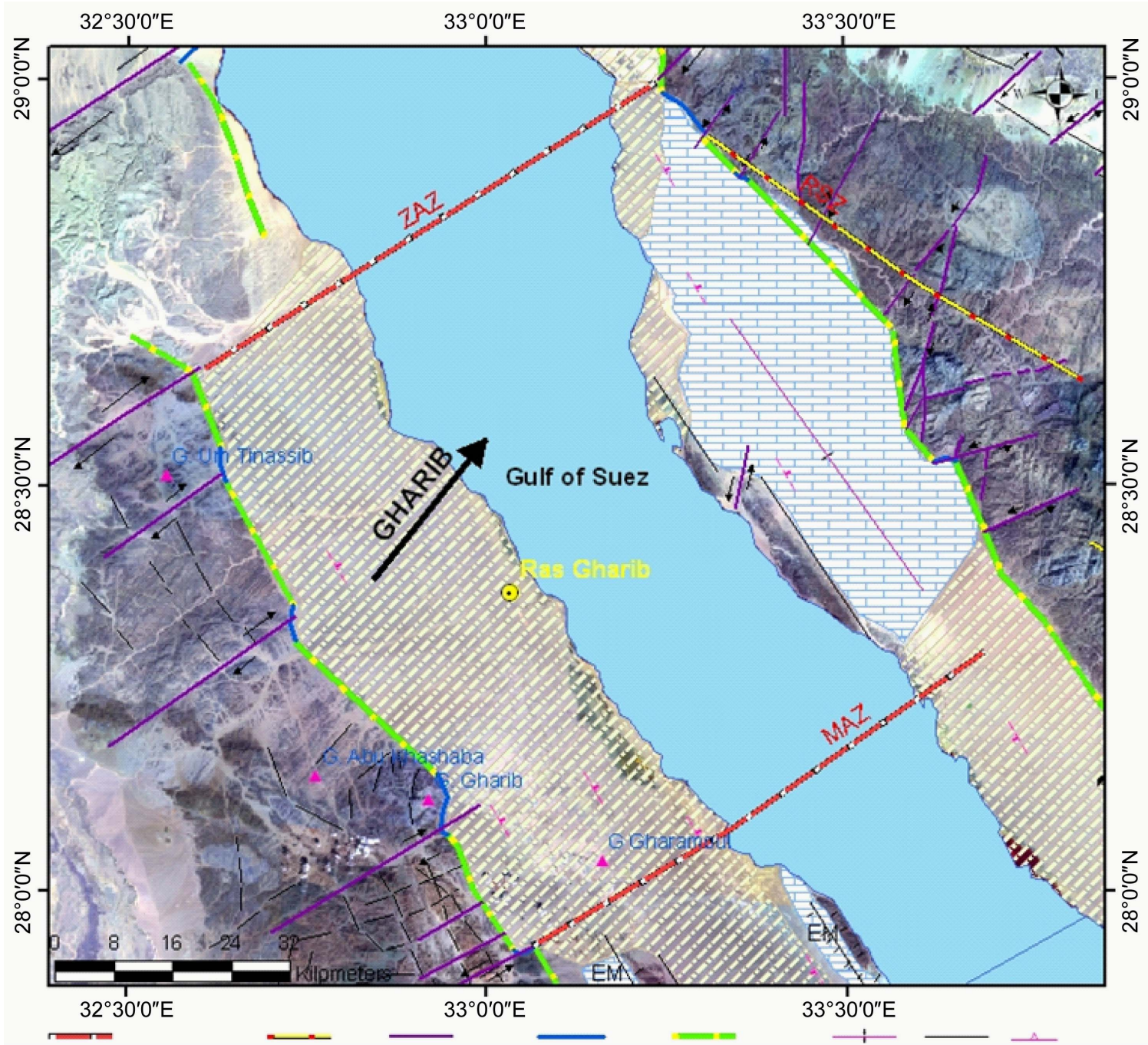

Accommodation zone Shear zone strike-slip fault Relay ramps Bounding faults Syncline Faults Bedstrike \& dip

Offshore sub-basins Coastal sub-basin Inland sub-basins

Figure 6. Landsat $\operatorname{ETM}^{+}$bands $(7,4,2)$ in red, green, and blue, shows the Gharib rift segment bounded from the north by the (ZAZ) Zaafaran Accommodation Zone, and from the south by the (MAZ) Morgan Accommodation Zone; (RSZ) Rihba Shear Zone. Small black arrows show the strike-slip movements of transfer faults.

\subsection{Structural Architecture of the Safaga Rift Segment}

The Safaga rift segment consists of five disconnected inland ESB include Esh El Mallaha; Um Taghir, Rabah, Wasif, and Um Huweitat, in addition to the coastal and offshore sub-basins (Figures 7 and 8). El Mallaha subbasin is the largest ESB in the Safaga rift segment. It is bounded on the north by the Morgan accommodation zone and on the south by the Dead Sea Transform Fault. It is bounded from the east by bounding fault dips to the $\mathrm{NE}$ and segmented into six segments with average strike $\mathrm{N} 30 \mathrm{~W}$ and connected by relay-ramps. The western bounding fault dips SW and consists of two segments with average strikes of $\mathrm{N} 35 \mathrm{~W}$ connected by relay-ramps. The relay-ramps developed at the intersection of the bounding fault and the NE-SW dextral strike-slip transfer faults. The inland ESB has NW antithetic extensional faults subparallel to the bounding faults (Figure 7).

Um Taghir sub-basin is the smallest inland ESB in the Safaga rift segment, covering an area of about $6 \mathrm{~km}^{2}$. The bounding fault here strikes N-S and dips to the E, and the sedimentary strata dip $20^{\circ} \mathrm{W}$. The bounding fault is truncated on the north and south ends by NE extensional faults (Figure 8).

The Rabah ESB covers an area about $20 \mathrm{~km}^{2}$ and the sedimentary strata dip $20^{\circ} \mathrm{SW}$. The bounding fault con- 


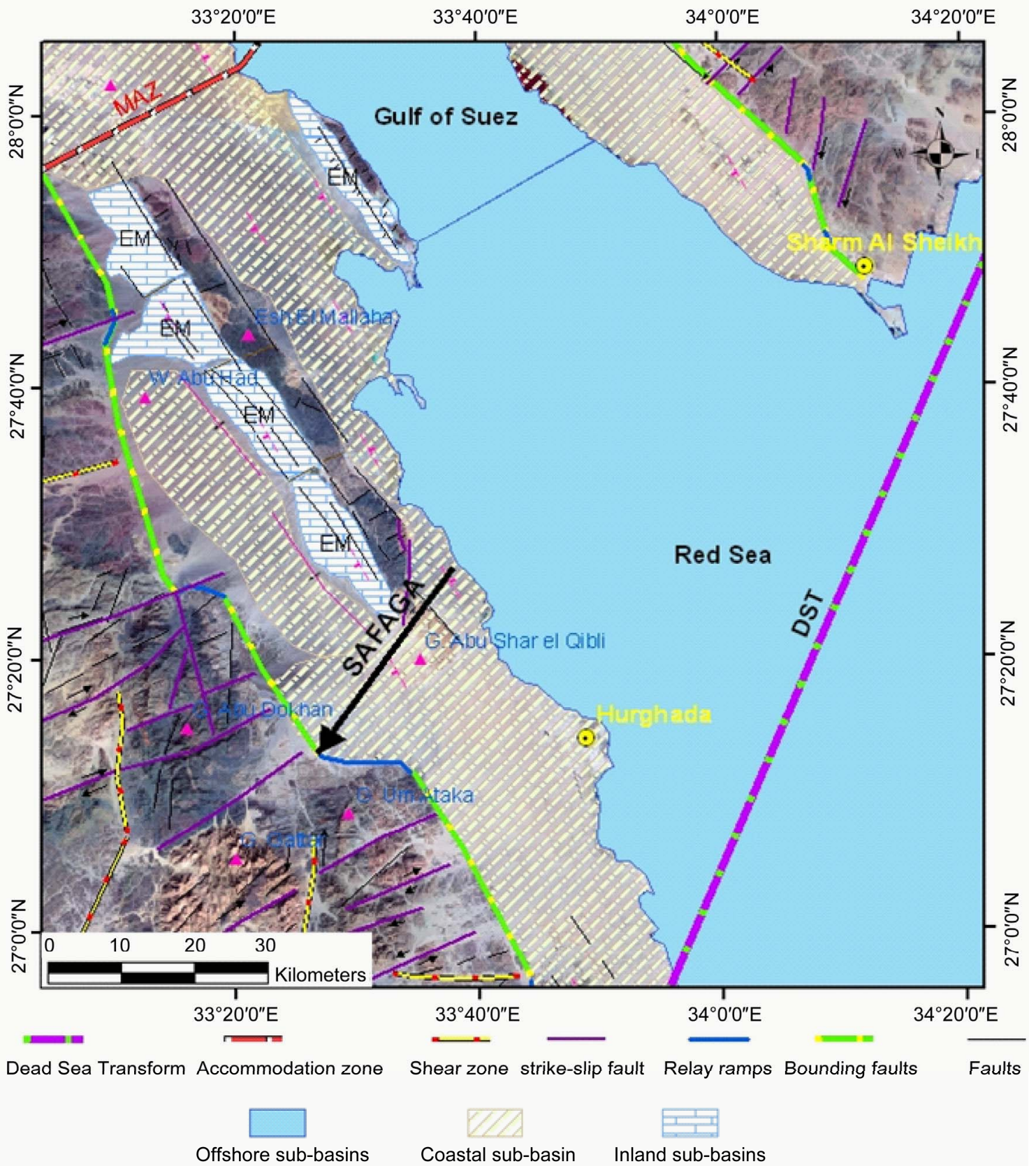

Figure 7. Landsat ETM $^{+}$bands $(7,4,2)$ in red, green, and blue, show half-graben Extensional Sub-Basins (ESB) of Esh El Mallaha and the (MAZ) Morgan Accommodation Zone. Small black arrows show strike-slip movement.

sists of two segments striking N35W and N10E from north to south, respectively, and connected by relay-ramps. It is terminated at its northern and southern ends by NE sinistral strike-slip faults. The relay-ramp developed at the intersection of the bounding fault and the NE-SW dextral strike-slip transfer fault (Figure 8).

Wasif ESB covers an area about $33 \mathrm{~km}^{2}$. The bounding fault is divided into two parts striking N-S and N40W and connected by relay-ramp. An extensional syncline developed against the northern segment of the bounding fault; some of the sedimentary rocks overlying the basement rocks on the hanging wall are dipping about $45^{\circ} \mathrm{E}$, while the strata of the Wasif ESB are found in the footwall and dip about $20^{\circ}$ to the W (Figures 8 and 9).

Um Huweitat ESB covers an area about $50 \mathrm{~km}^{2}$ and is bounded by a fault striking NNW and dipping $40^{\circ} \mathrm{E}$. It is segmented into five parts by dextral strike-slip transfer faults that are connected by relay-ramps. The NE-SW transfer faults extended into the basement rocks found between Um Huweitat and Wasif ESB and are termi- 


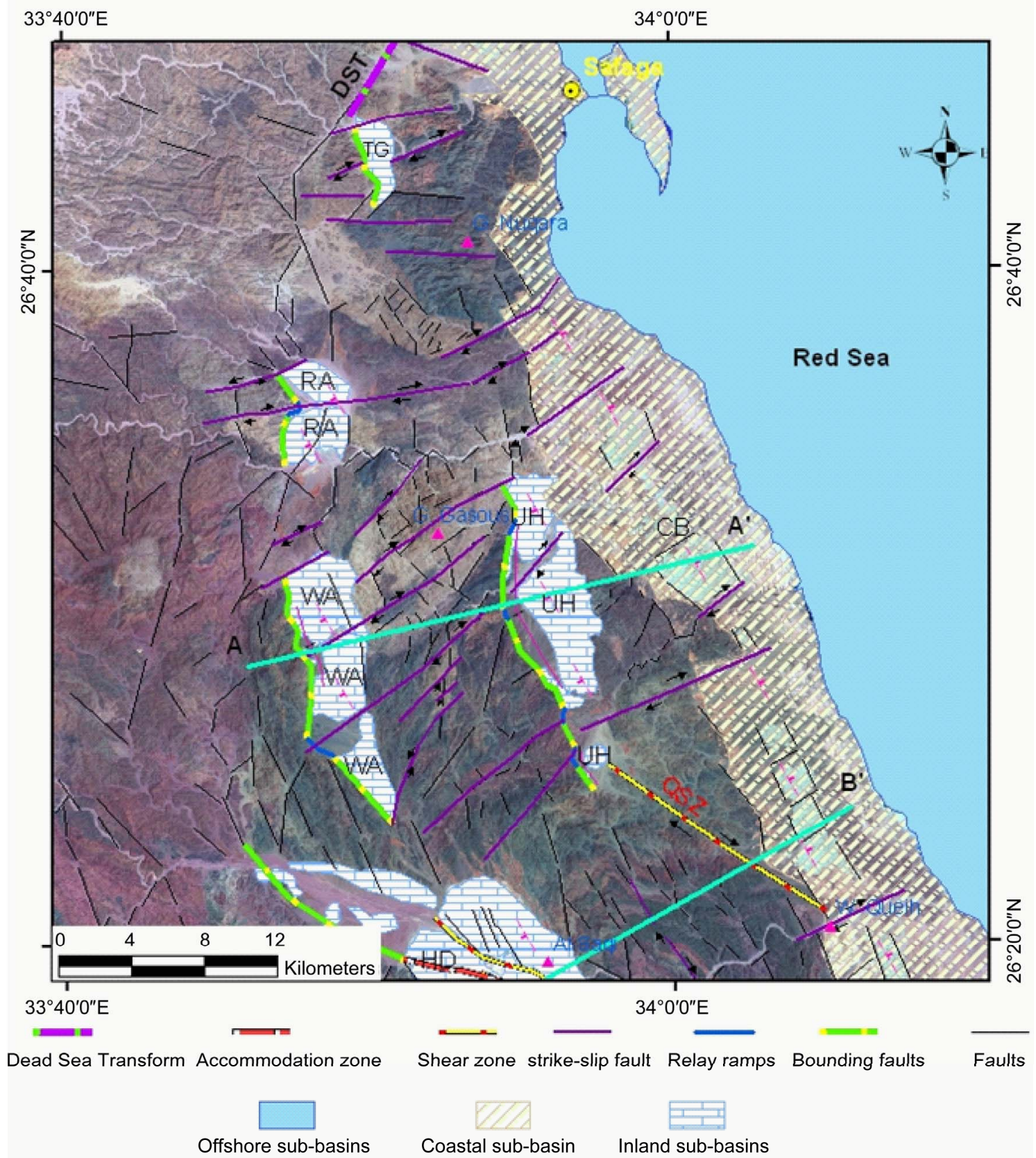

Figure 8. Landsat $\operatorname{ETM}^{+}$bands $(7,4,2)$ in red, green, and blue, shows half-graben Extensional Sub-Basins (ESB) of (TG) Um Taghir; (RA) Rabah; (WA) Wasif; (UH) Um Hewitat; (CB) Coastal Basin; (DAZ) Duwi Accommodation Zone; (QSZ) Queih Shear Zone. Small black arrows show strike-slip movement; A-A' cross-section.

nated at the bounding fault of the Wasif ESB. This may indicate they are pre-rift faults that were reactivated by rifting due to NE-SW extension. The strata of the Um Huweitat blocks change their dip from $13^{\circ} \mathrm{W}$ in the northern part to $15^{\circ} \mathrm{W}$ in the middle, and $25^{\circ} \mathrm{W}$ in the southern part. This is attributed to dextral strike-slip movement of transfer faults due to NW-SE extension that resulted in translation of the Um Huweitat bounding fault (Figures 8 and 9).

\subsection{Structural Architecture of the Qusier Rift Segment}

The Qusier rift segment consists of five disconnected inland ESB - Gabal Duwi, Nakhil, Atshan, Hamadat, and Zog el-Bohar-in addition to coastal and offshore subbasins (Figures 10 and 11).

Gabal Duwi sub-basin is the largest inland ESB in the Eastern Desert of Egypt, covering an area of approximately $300 \mathrm{~km}^{2}$ (Figure 10). It is bounded by a SW- 


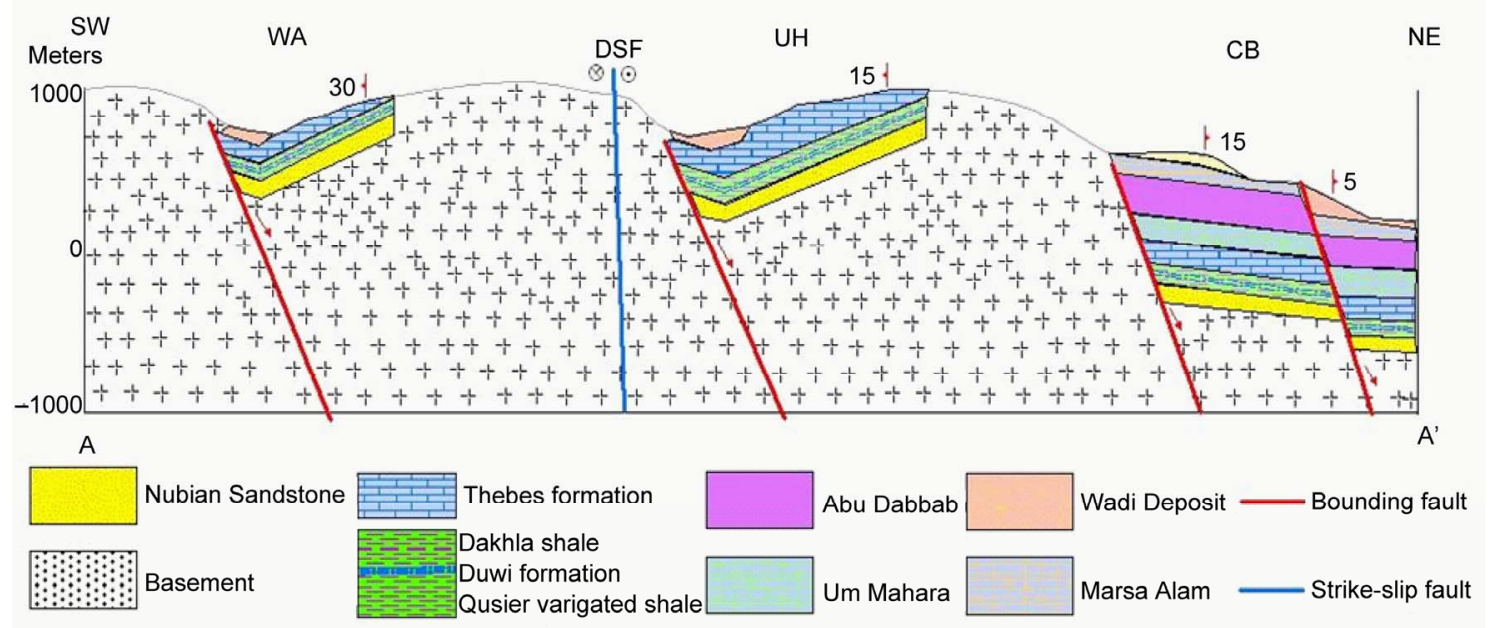

Figure 9. Regional cross-section A-A' (location is shown in Figure 5) across extensional sub-basins of Wasif (WA); Um Hewitat (UH); and Coastal Sub-Basin (CB); (DSF) Dextral Strike-Slip Fault.

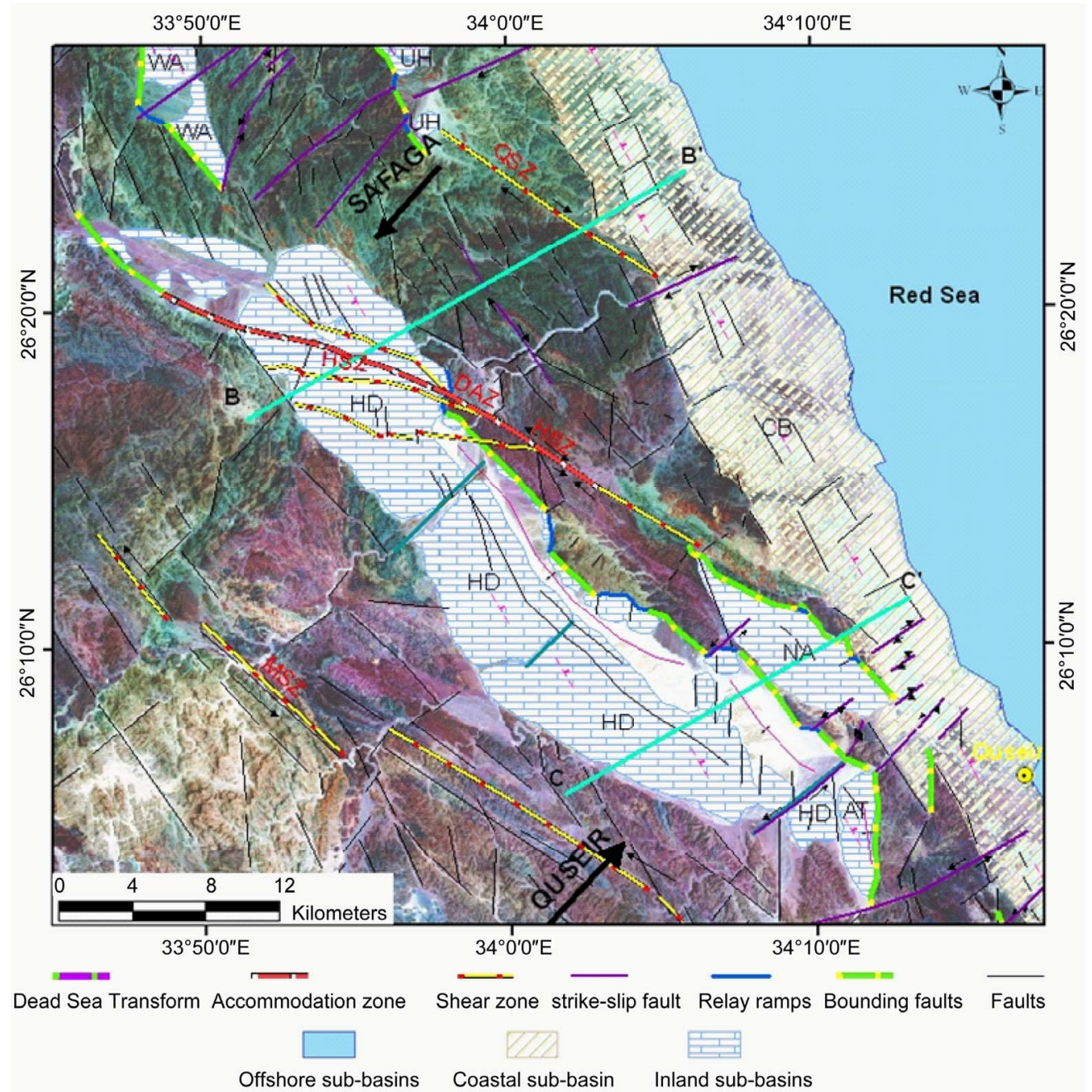

Figure 10. Landsat $\operatorname{ETM}^{+}$bands $(7,4,2)$ in red, green, and blue, shows half-graben extensional sub-basins (ESB) of Um Hammad-Duwi (HD); (NA) Nakhil; and (AT) Atshan sub-basins; (CB) Coastal Basin; (DAZ) Duwi Accommodation Zone; (MSZ) Meatiq Shear Zone; (QSZ) Queih Shear Zone; (HSZ) Hamraween Shear Zone. Small black arrows show strike-slip movement; B-B' and C-C' cross sections. 


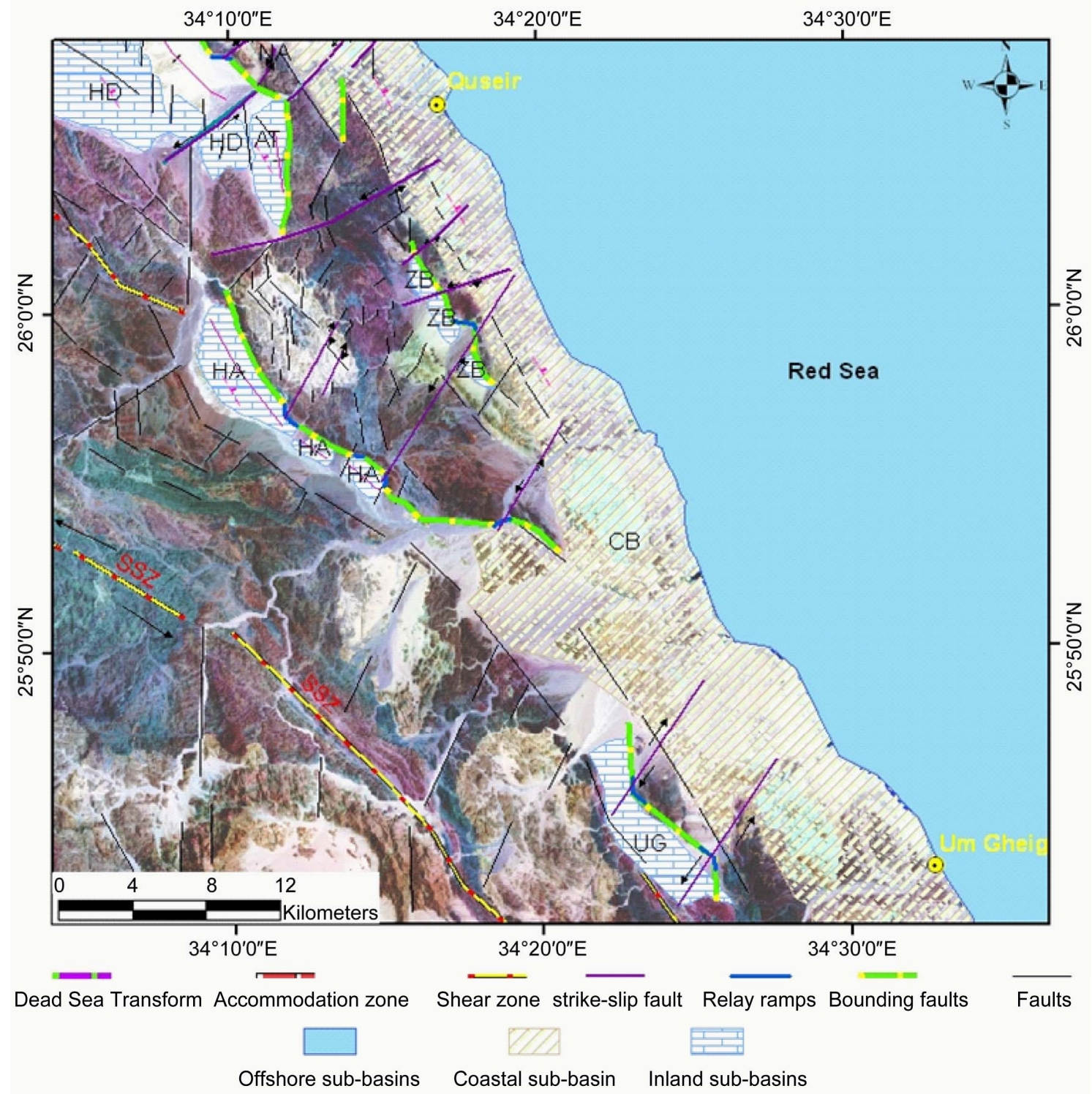

Figure 11. Landsat $\mathrm{ETM}^{+}$bands $(7,4,2)$ in red, green, and blue, shows the sedimentary sub-basins ESB) of (HA) Hamadat; (ZB) Zog el Bohar; and (UG) Um Gheig. (CB) Coastal Basin; (SSZ) Sibai Shear Zone. Small black arrows show strike-slip movement.

dipping bounding fault that extends for about $30 \mathrm{~km}$ to the northwest. The fault juxtaposed the Eocene Thebes Formation against basement rocks with about $1000-1300$ $\mathrm{m}$ of offset (Mustafa, 1997, [11]). It is segmented into six segments with an average strike of N40W and connected by relay-ramps. The Precambrian basement rocks on the eastern side of the bounding fault represent the footwall, and the Phanerozoic sedimentary rocks of Gabal Duwi comprise the hanging wall and dip $20^{\circ} \mathrm{NE}$. Large extension-related asymmetric synclines formed in the hanging wall because of slip on the bounding fault [41].

The Gabal Duwi ESB is divided into four blocks separated by three NE-SW oblique-slip faults (Figure 10). These blocks were subjected to translation because of change in the extension vector and the development of transfer faults. The Gabal Duwi ESB is traversed by two antithetic NW extensional internal fault "domino-like" fault blocks with down throw about $2 \mathrm{~m}$ to the NE. The northern part of Gabal Duwi is divided into the northern Al Saqi and southern Sodmain blocks [25]. These blocks are separated by the NW-trending Hamraween Shear Zone, which splays into four branches at its intersection with the bounding fault. The main branch represents the Duwi accommodation zone between the SW-dipping Safaga rift segment and the NE-dipping Qusier rift segment. The opposing dips of the Al Saqi block and the Sodmain block form a syncline with a hinge line that lies within the Duwi accommodation zone [25]. The Ham- 
raween Shear Zone splays were reactived by NE-SW extension that resulted in the development of negative flower structures in the Al Saki and Sodmain blocks.

The Nakhil sub-basin covers an area about $28 \mathrm{~km}^{2}$. Strata within the basin dip $20^{\circ} \mathrm{NE}$. The bounding fault dips to the SW and has an average strike of $\mathrm{N} 40^{\circ} \mathrm{W}$, paralleling the Gabal Duwi bounding fault. It is divided into four segments by movement on NE-SW dextral strikeslip faults that are connected by relay ramps. It is terminated at its northern end by the Hamraween Shear Zone and at its southern end by a NE dextral strike-slip fault (Figures 10 and 12).

The Atshan sub-basin covers an area of approximately $14 \mathrm{~km}^{2}$. The bounding fault dips to the SW and strikes N-S. Sedimentary strata dip about $20^{\circ} \mathrm{E}$. The Atshan subbasin is the only ESB in the Quseir rift segment that is bounded by a N-S bounding fault (Figure 10).

The Hamadat sub-basin covers an area of approximately $27 \mathrm{~km}^{2}$. It is bounded on the east side by a bounding fault dips SW and is divided into three segments by NE-SW strike-slip faults that are connected by relay ramps. There are three extension-related synclines developed on the hanging wall opposite to each segment of the bounding fault [41] (Figure 11). Strata dip $25^{\circ}$ to the northeast and form the long limb of the synclines. The second, shorter limb is comprised of the sedimentary units that overly basement rocks and dips $45^{\circ}$ to the southwest.

Zoug el Bohar sub-basin covers an area about $10 \mathrm{~km}^{2}$ and is separated from the Hamadat and coastal sub-basins by basement rocks. The bounding fault dips to the $\mathrm{SW}$ with an average strike of $\mathrm{N} 35^{\circ} \mathrm{W}$ and is divided into two parts by a NE-trending sinistral strike-slip fault (Figure 11).

The Um Gheig sub-basin covers an area of approximately $26 \mathrm{~km}^{2}$. It is bounded by bounding fault which dips SW. The bounding fault is intersected by two NEtrending strike-slip transfer faults that have segmented it into three parts connected by relay-ramps. The transfer faults are active; they affect the recent deposits of syn-rift and post-rift sediments in the coastal sub-basin, and have induced displacement of the bounding fault. The Um Gheig sub-basin consists entirely of recent wadi wash deposits and does not have pre-rift or syn-rift deposits (Figure 11).

The coastal sub-basin extends along the Safaga and Quseir rift segments from its contact with basement rocks to the shoreline and offshore continental shelf. The width of the coastal sub-basin is greater in the Gulf of Suez rift segment than the other rift segments. The coastal subbasin strata dip to the northeast, indicating they are bounded by an antithetic extensional fault that dips to the southwest (Figures 5 to 12). The sedimentary succession of
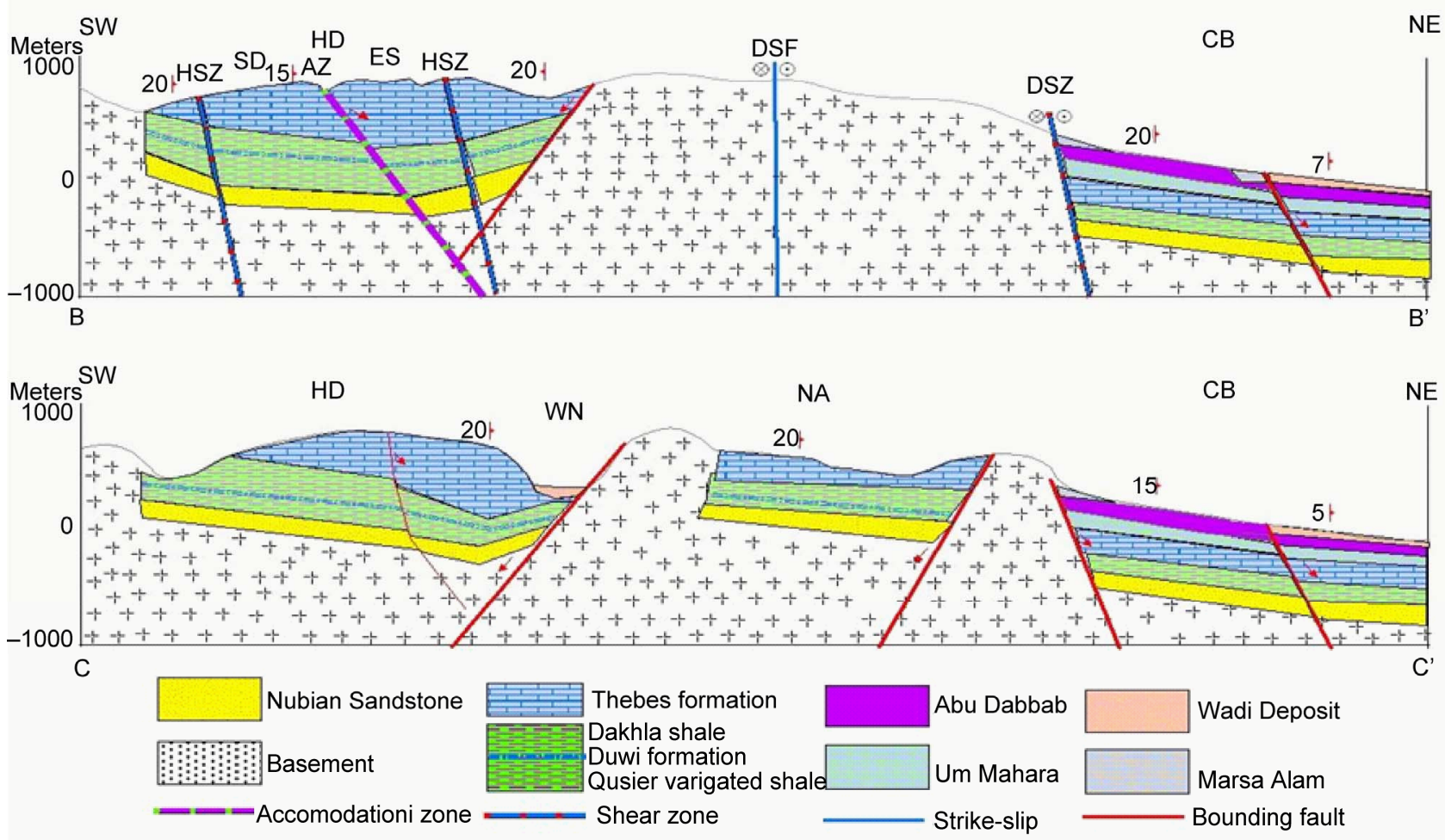

Figure 12. Regional cross-section B-B' and C-C' (location is shown in Figure 7) across extensional sub-basins of Um Hammad-Duwi (WA); Nakhil (NA); and Coastal Basin (CB); (SD) Sodmain Block; (ES) El Saki block; (WN) Wadi Al Nakhil; (DAZ) Duwi Accommodation Zone; (HSZ) Hamraween Shear Zone; (QSZ) Queih Shear Zone; (DSF) Dextral Strike-Slip Fault. 
the coastal sub-basin consists of pre-rift, syn-rift, and postrift sediments unconformably overlying the basement rocks and exposed from older to younger when traversed from west to east. The coastal sub-basin is cut by two NW-SE sub-parallel rift-related internal faults that dip to the NE and have created "domino-like" fault blocks. The dip of strata changes from $40^{\circ} \mathrm{NE}$ at the contact with basement rocks to approximately $15^{\circ}-25^{\circ} \mathrm{NE}$ ) in the middle and only $10^{\circ}-5^{\circ} \mathrm{NE}$ ) at the shoreline. The change in dip of sedimentary units is interpreted to be the result of differential slip on the internal faults. The coastal sub-basin is also cut by NE-SW strike-slip transfer faults that have displaced both the sedimentary units and other internal faults.

\subsection{Accommodation Zones (AZ)}

Accommodation zones occur between adjacent halfgraben basins that switch dip-polarity $[11,25]$. Accommodation zones in rift systems are typically $15-30 \mathrm{~km}$ wide [42] and show a wide range of deformation that include faults affected by normal slip, oblique-slip, and strike-slip movement [43]. Younes and McClay proposed a model for localization of accommodation zones in the Gulf of Suez and northwestern Red Sea [11]. The model shows that accommodation zones developed at the intersection between rift-related bordering faults and preexisting W-NW and N-S shear zones that were reactivated by the Oligocene-early Miocene N60E extension. This resulted in left-lateral and right lateral oblique-slip on the N-S and W-NW shear zones, respectively, and changed the dip direction of sediments within the ESB. The accommodation zones offset the axial depressions of the northern Red Sea [8]. The study area has three accommodation zones the Zaafarana, the Morgan, and the Duwi separateing the Suez, Gharib, Safaga, and Quseir rift segments, respectively (Figure 2).

Younes and McClay proposed the Zaafarana accommodation zone has a NW-SE trend and is located at the intersection between the pre-existing NW-trending Rihba shear zone and the rift bounding faults [11]. Moustafa and Khalil [44] suggested that the Zaafarana accommodation zone is oriented NE-SW and controlled by Wadi Araba folding which is part of the Syrian Arc system. Herein we propose that the Zaafarana accommodation zone is developed on pre-existing NE-SW oblique-slip that juxtaposes pre-rift and syn-rift deposits of the coastal ESB against the eastern side of the Gulf of Suez, and on the western side, places the pre-rift succession of El Galala El Qibliya against basement rocks. Our interpretation is based on several key observations: 1) Zaafarana accommodation is represented by the intersection between a NE-SW right-oblique fault with downthrow to the north and the bounding fault; 2) it represents the northern end of basement rock exposure on both sides of the Gulf of Suez and juxtaposes pre-rift and syn-rift sediments against the basement rocks; 3) kinematically, right-lateral movement on this NE-SE oblique-slip fault accompanied by the NE-SW extension could account for the development of southwesterly dips in the Suez rift segment, and northeasterly dips in the Gharib rift segment; 4) the coastal ESB switched their depocenters from east to west; and 5) the dominant fault trend in the Gulf of Suez region is NE-SW (Figures 5 and 6).

The Morgan accommodation zone inherited its ENEWSW orientation from pre-existing faults. Sinistral strikeslip movement is related to the rotation of the rift blocks [25]. We agree with this conclusion based on the following: 1) the Morgan accommodation zone is marked by the intersection between the rift-bounding fault and a pre-existing NE-SW left-oblique fault with downthrow to the north, and parallels the dominant NE-SW-oriented strike-slip faults in the Gulf of Suez region (Figures 5 and 6);2) the coastal ESB and the inland ESB switched their depocenters from the eastern to western side of the Gharib rift segment and the northern part of the Safaga rift segment (Esh El Mallaha ESB); 3) the narrow strip of basement rocks within the Gharib rift segment on the western side of the Gulf of Suez has the same lithologies as Sinai basement rocks and is terminated at its southern end by the accommodation zone, and the basement strips of Esh El Malaha on the western side of the Gulf of Suez of the Safaga rift segment have the same rock types as the Northern Eastern Desert basement complex and is terminated at its northern end by the Morgan accommodation zone; 4) the inland ESB of Gharib is filled with sediments from Cambrian to recent while the ESB of Esh El Mallah has sediments from Upper Cretaceous to recent, which indicates the Morgan accommodation zone has been developed on a pre-rift oblique-slip fault that submerged the northern Arabian Nubian Shield during the Cambrian time while keeping the southern ANS above sea level until the upper Cretaceous; 5) kinematically, sinistral strike-slip movement combined with NESW extension and a SW-dipping bounding fault would result in NE-dipping strata in the Gharib ESB (Figure 6).

The Duwi accommodation zone strikes NW-SE and is marked by the intersection between the SW-dipping bounding fault and the Hamraween Shear Zone [11]. Analysis and interpretation of Landsat $\mathrm{ETM}^{+}$imagary shows dextral strike-slip movement within the Hamraween shear zone is recorded by the displacement of NE-trending fractures in basement rocks (Figure 10). Field investigations revealed the presence of kinematic indicators including strike-parallel grains and mineral lineations in green breccias at the entrance of Wadi Al Saqi. Shearsense indicators and quartz-filled en-echelon fractures in metavolcanics suggest old sinistral displacements. 
Displacement along the Hamraween Shear Zone switched from left-lateral displacement in conjunction with the Najd Fault System, to right-lateral movement due to NE-SW extension [11,23]. Kinematically, dextral strikeslip movement of the Hamraween Shear Zone accompanied by NE-SW extension would result in a SW-dipping bounding fault and northeasterly dipping strata in Gabal Duwi.

\section{Kinematic Model for the Development of the Half-Graben Extensional Sub-Basin}

A model was developed by Agostini et al. to explain the rifting of continental lithosphere that contains a preexisting zone of weakness [40]. The model shows that the deformation pattern is controlled by the angle between the extension direction and the pole to the plane of rifting. When the applied extension was perpendicular to the weakness zone, orthogonal rifting developed and marginal grabens delimited a central horst. Increased extension developed internal faults and formed a graben within the central horst. Increasing displacement on the internal faults resulted in deepening the central graben, forming a rift depression flanked with marginal grabens [40]. A change of extension direction generated oblique rifting which was characterized by en-echelon boundary faults bordering subsiding rift blocks and linked by a complex of transfer zones [40].

The Gulf of Suez and Red Sea were developed in the late Oligocene to early Miocene about (30 Ma) [2]. They opened with an axial rift strike of $\mathrm{N} 30 \mathrm{~W}$, with very low amounts of extension directed at N60E [11,45]. During the initial stage of the Gulf of Suez rifting, the rate of subsidence was very low, increasing in the early Miocene as evidenced by rapid subsidence, and slowed again by the middle Miocene [45].

We developed a model that describes the kinematic stages of the northern Red Sea and Gulf of Suez rifting and development of the marginal ESB based on structural analysis of inland and coastal ESB. The results show that the Red Sea and Gulf of Suez rifting is polyphase and occurred in three different extension directions. The first phase was dominated by orthogonal rifting in response to $\mathrm{N} 60 \mathrm{E}$ extension that started in the late Oligocene to early Miocene (30 - $24 \mathrm{Ma})$. The angle between the extension direction and the rift trend was right angle $\left(\theta=90^{\circ}\right)$ (Figure 13(a)). The rift started by nucleation of bounding faults that followed major pre-existing weak zones but individually were perpendicular to the extension direction. The first marginal ESB (currently the inland and coastal ESB) were formed by slip on NE-dipping bounding fault, resulting in subsidence of the pre-rift succession. The Tethys Seaway covered the sub-sided ESB, resulting in the deposition of the syn-rift Al Nakhil Formation during the late Oligocene. A change of stress direction is indicated by a paleostress analysis of markers within the Duwi ESB, which show that it was formed at principal stress directions with sub-horizontal $\sigma_{1}$ is (ENE-WSW), and $\sigma_{3}$ is (NNW-SSE), and a subvertical $\sigma_{2}$ [27]. Increasing extension formed the SWdipping internal antithetic extensional faults in the ESB. These faults are found in the Um Huwitat, Gabal Duwi, and coastal ESB. They are sub-parallel to the bounding fault and form a "domino-like" pattern of fault blocks (Figure 12). There are several SW-dipping extensional faults that strike N-S and NNW in basement rocks and were developed in response to E-W and NE-SW extension, which supports our inferences.

The second phase of rifting started in the early to middle Miocene (24 - $18 \mathrm{Ma}$ ) by increased the NE extension, as indicated by increasing slip on the internal faults and deepening of the central graben. This is supported by $\sim 1200 \mathrm{~m}$ deposits of the lower Miocene in the Gulf of Suez, including the subsurface Nukhul and Rudeis Formations [38]. The direction of extension began to rotate anticlockwise and the flanks were uplifted, resulting in uplift of the marginal ESB (currently inland ESB). Deposition was interrupted in these ESB, either due to uplift or regression of the Tethys Sea, so that only the rift depression was marine (Figure 13(b)). This is indicated by the presence of early Miocene deposits in the coastal ESB overlying the pre-rift succession and syn-rift Late Oligocene-aged Al Nakhil Formation. By the middle Miocene, the extension direction changed to be N40E which shifted the rifting from orthogonal to oblique $\left(\theta=70^{\circ}\right)$. The oblique rifting resulted in fragmentation of the rift depression into en-echelon rift segments separated by oblique-slip accommodation zones (Figure 2 and 13(b)).

The third phase, which includes ongoing rifting, started in the middle Miocene $(\sim 18 \mathrm{Ma})$ by increased extension at $\mathrm{N} 40 \mathrm{E}$ associated with a N50W compression that produced the left-lateral Dead Sea Transform between the Arabian plate and the Sinai Peninsula [31,46-48]. The segmentation of the rift appears to have occurred before the development of the Dead Sea Transform because the extension of the Dead Sea Transform in the northern Eastern Desert separated the Safaga rift segment into two parts (Figure 2). The sinistral strike-slip movement of the Dead Sea Transform resulted in clockwise rotation of the extension direction, which lowered the opening rate to $<1 \mathrm{~mm} / \mathrm{yr}$ in the Gulf of Suez [45]. The slowdown of the Gulf of Suez rift rate coincides with its separation from the main rift (Red Sea), which continues to open by oblique rifting (Figure 13(c)). Oblique rifting in the Red Sea developed new internal faults and more offshore ESB and deepened the rift depression, and offers a simple explanation for why the rate of Red Sea rifting is seven times greater than the rate for the Gulf of Suez during the last $18 \mathrm{Ma}$. The current western bounding fault 
(a)

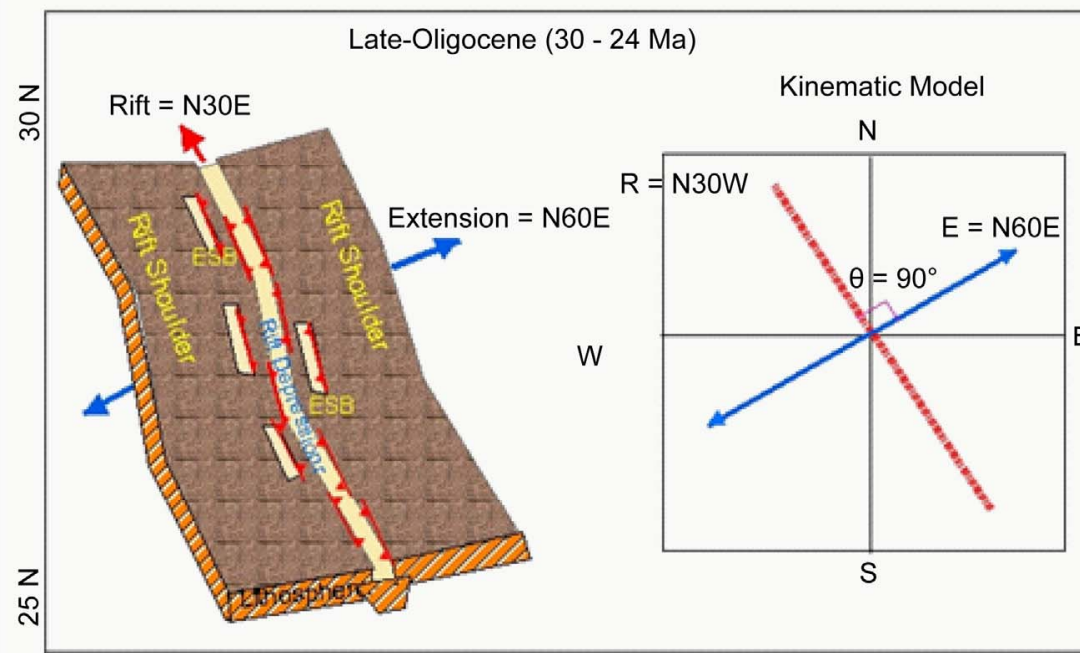

(b)

(c)

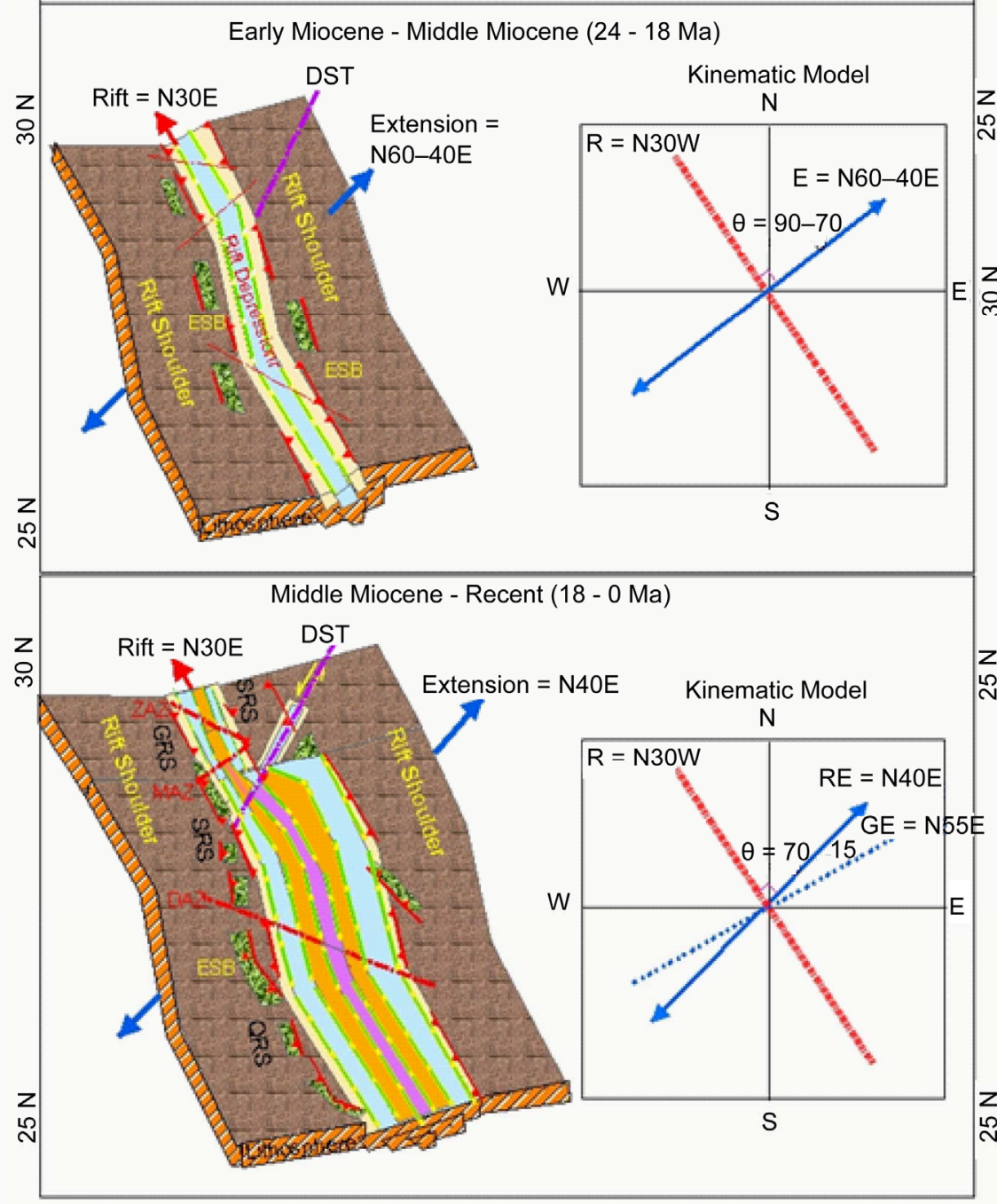

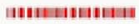

으 Rift direction
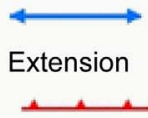

Bounding Fault

Internal extension fault

Dead Sea Transform

..................

Accommodation Zone

Current extension of Gulf of Suez

Z

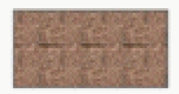

Rift Shoulder

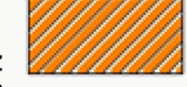

Lithosphere

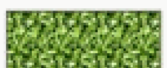

Inland Basin

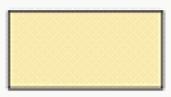

Coastal Basin

in

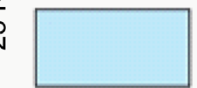

Offshore Basin $z$

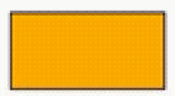

Gulf of Suez Rift Depression

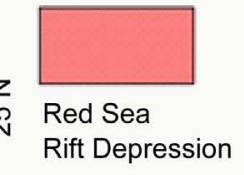

Figure 13. Evolutionary kinematic model demonstrate polyphase rifting of the northern Red Sea and Gulf of Suez, and development of the rift segments and the marginal half-graben extensional sub-basins (ESB). (DST) Dead Sea Transform; (SRS) Suez Rift Segment; (GRS) Gharib Rift Segment; (FRS) Safaga Rift Segment; (QRS) Quseir Rift Segment; (ZAZ) Zaafarana accommodation zone, (MAZ) Morgan Accommodation Zone; (DAZ) Duwi Accommodation Zone; (EM) Esh Al Malaha halfgraben sub-basin; (UH) Um Huweitat half-graben sub-basin; (HD) Um Hammad-Duwi half-graben sub-basin; (HA) Hamadat half-graben sub-basin. 
of the Gulf of Suez has average strike N35W, which indicates that the current extension direction in the Sinai Peninsula is now N55E (Figure 13(c)). Therefore, the Gulf of Suez rifting has changed again to almost orthogonal rifting $\left(\theta=85^{\circ}\right)$. Slip rates on the bounding fault were very low but were higher on the internal faults and the rift depression, as indicated by deposition of almost $1900 \mathrm{~m}$ of sediment during the last $7 \mathrm{Ma}$; include the Zeit, Wardan, and Zaafarana Formations [38]. Flank uplift continued and resulted in formation of marginal coastal ESB that have early Miocene deposits overlying the pre-rift and syn-rift of late Oligocene and early Miocene deposits, which were then overlain by post-rift deposits. The coastal ESB is wide in the Gulf of Suez because of orthogonal rifting and small in the northwestern Red Sea due to oblique rifting. Oblique extension in the northern Red Sea resulted in an en-echelon distribution of the inland ESB and development of NE-SW sinistral and dextral strike-slip transfer faults to accommodate the increasing N40E extension, resulting in rotation and translation of some of the bounding fault (Figures 2-13).

\section{Discussion and Conclusions}

Transgression of the Tethys Sea from north to south and the active oblique-slip faults in the northern ANS resulted in deposition of a thick $(\sim 2000 \mathrm{~m})$ pre-rift succession of Cambrian to Eocene sediments in the Gulf of Suez region. The pre-rift succession in the northwestern Red Sea is approximately 400 - $500 \mathrm{~m}$ thick [25] and was deposited during the late Cretaceous to Eocene, indicating this region was predominantly continent during the Paleozoic and most of the Mesozoic. The introduction of N60E extension and the presence of NW and N-Strending zones of lithospheric weakness within the ANS resulted in the nucleation of rift-bounding faults by orthogonal rifting. Increased extension in the late Oligocene led to the formation of marginal half-graben extensional sub-basins (ESB) that represent the current inland and coastal ESB. Slip on the boundary faults resulted in subsidence and submergence of the pre-rift succession, leading to deposition of the Late Oligocene the Nakhil Formation. This indicates the ESB were formed as extensional basins rather than pull-apart basins. The inland ESB are now isolated because their bounding faults developed on pre-existing weak zones that were crosscut by relatively competent younger rocks that interrupted the continuity of the bounding faults. These younger rocks, including granites and the Dokhan volcanics, were emplaced during the final stages of the Pan-African orogeny $[19,49]$ and yield ages of 605 - $595 \mathrm{Ma}$ and 600 - $590 \mathrm{Ma}$, respectively [50,51]. The Um Huweitat ESB is separated from the Wasif ESB by the younger granitic plutons of Gabal Gasus, and the Duwi ESB is separated from the
Wasif ESB by the Dokhan volcanics.

The presence of early Miocene sediments in the coastal ESB indicate that the rift flanks were uplifted and slip increased on internal faults, resulting in the formation of marginal (currently coastal) ESB. Segmentation of the rift depression and development of the Dead Sea Transform during the middle Miocene (ca. $18 \mathrm{Ma}$ ) resulted from $\mathrm{N} 40^{\circ}$ E-oriented extension, indicating the rift had switched from orthogonal to oblique. The rift segments are separated by oblique-slip accommodation zones that were developed on pre-existing NE-SW strike-slip faults in the Gulf of Suez region and on the NW-SE Hamraween Shear Zone in the northwestern Red Sea. Increased oblique extension led to the development of an en-echelon distribution of the inland ESB and translation of the bounding faults. The Gulf of Suez was separated from the Red Sea because of sinistral strike-slip movement of the Dead Sea Transform, which slowed the rift rate within the Gulf of Suez and increased oblique rifting in the Red Sea. During the last $18 \mathrm{Ma}$ (after development of the Dead Sea Transform), the Red Sea has become seven times wider than the Gulf of Suez by developing more antithetic internal faults, which has led to an expansion of offshore ESB and a deepening of the rift depression [8]. The Dead Sea Transform movement also rotated the extension direction of the Gulf of Suez, which has widened the marginal coastal ESB more than the Red Sea coastal ESB.

Oblique rifting in the Red Sea resulted in development of NE-SW sinistral and dextral strike-slip transfer faults to accommodate the ongoing N40E extension. The transfer faults are active, as evidenced by their displacement of the bounding faults. This has affected recent deposits in the coastal plain and may be a source of earthquakes $[52,53]$. It is believed that the inland ESB release the stress that has resulted from the accumulated strain on the transfer faults, because most of the transfer faults truncate within the inland ESB and do not continue into basement rocks. Strata within coastal ESB in the Safaga and Quseir rift segments dip to the NE and do not change their dipping direction across the Duwi accommodation zone because they are controlled by slip on a SW-dipping antithetic internal fault. Increased NE extension has increased the slip on the internal fault, and therefore, the accommodation zone has changed the dip of the inland ESB strata and bounding fault but has not affected the dip direction of the coastal ESB. The marginal ESB found on the western side of the Red Sea preserve prerift sediments while the single marginal ESB on the eastern side of the Red Sea contains no pre- or syn-rift deposits. The eastern marginal ESB formed in the Ajjaj shear zone (a branch from the Najd fault system) and is interpreted to have formed recently due to oblique extension. This interpretation is consistent with the presence of 
a detachment fault that extends from near the surface on the western rift shoulder and roots in the middle crust beneath the eastern rift shoulder [5].

This study suggested a new model to describe northern Red Sea and Gulf of Suez rifting and the development of marginal ESB. The model results indicate the Red Sea has developed through multiple phases of rifting that have been controlled by the direction of extension and preexisting lithosphere weak zones. We propose that inland ESB were formed by orthogonal rifting during the first stages of the Red Sea rift and were later uplifted along the rift flanks during the next stage of oblique rifting. The model also relates development of the Gulf of Suez to sinistral strike-slip movement along the Dead Sea Transform, which arrested the Gulf of Suez opening by clockwise rotation of the Gulf of Suez extension direction. This model may be broadly applicable to the development of marginal ESB in any active rift system.

\section{Acknowledgements}

The authors would like to thank the Egyptian Ministry of Higher Education and Scientific Research for supporting this work. Many thanks for The Land Processes Distributed Active Archive Center (LP DAAC) at NASA for providing Landsat ETM data.

\section{REFERENCES}

[1] W. Ghebreab, "Tectonics of the Red Sea Region Reassessed," Earth Science Reviews, Vol. 45, No. 1-2, 1998, pp. 1-44. doi:10.1016/S0012-8252(98)00036-1

[2] W. Bosworth, P. Huchon and K. McClay, "The Red Sea and Gulf of Aden Basins," Journal of African Earth Sciences, Vol. 43, No. 1-3, 2005, pp. 334-378. doi:10.1016/i.jafrearsci.2005.07.020

[3] J. D. Lowell and G. J. Genik, "Sea Floor Spreading and Structural Evolution of Southern Red Sea," AAPG Bulletin, Vol. 56, No. 2, 1972, pp. 247-259.

[4] J. R. Cochran and F. Martinez, "Evidence from the Northern Red Sea on the Transition from Continental to Oceanic Rifting," Tectonophysics, Vol. 153, No. 1-4, 1988, pp. 25-53. doi:10.1016/0040-1951(88)90006-6

[5] R. G. Bohannon, C. W. Naeser, D. L. Schmidt and R. A. Zimmerman, "The Timing of Uplift, Volcanism, and Rifting Peripheral to the Red Sea: A Case for Passive Rifting," Journal of Geophysical Research, Vol. 94, No. B2, 1989, pp. 1683-1701. doi:10.1029/JB094iB02p01683

[6] J. Makris and R. Rhim, "Shear Controlled Evolution of the Red Sea: Pull Apart Model," Tectophysics, Vol. 198, No. 2-4, 1991, pp. 441-446. doi:10.1016/0040-1951(91)90166-P

[7] N. Bellahsen, C. Faccenna, F. Funiciello, J. Daniel and L. Jolivet, "Why Did Arabia Separate from Africa?" Insights from 3-D Laboratory Experiments, Earth \& Planetary Science Letter, Vol. 216, No. 3, 2003, pp. 365-381. doi:10.1016/S0012-821X(03)00516-8
[8] J. Cochran, "Northern Red Sea: Nucleation of an Oceanic Spreading Center within a Continental Rift," Geochemistry Geophysics Geosystems, Vol. 6, 2005, p. 34. doi:10.1029/2004GC000826

[9] T. H. Dixon, R. J. Stern and I. M. Hussein, "Control of Red Sea Rift Geometry by Precambrian Structures," Tectonics, Vol. 6, No. 5, 1987, pp. 551-571. doi:10.1029/TC006i005p00551

[10] W. Bosworth, "A Model for the Three-Dimensional Evolution of Continental Rift Basins, North-East Africa," In: H. Schandelmeier and R. J. Stern, Eds., Geology of Northeast Africa, Geologische Rundschau 83, 1994, pp. 671-688.

[11] A. Younes and K. McClay, "Development of Accommodation Zones in the Gulf of Suez-Red Sea Rift, Egypt," AAPG Bulletin, Vol. 86, No. 6, 2002, pp. 1003-1026.

[12] R. J. Stern and C. E. Hedge, "Geochronologic and Isotopic Constraints on Late Precambrian Crustal Evolution in the Eastern Desert of Egypt," American Journal of Science, Vol. 285, 1985, pp. 97-1 27.

[13] A. Krőner, J. Krüger and A. Rashwan, “Age and Tectonic Setting of Granitoid Gneisses in the Eastern Desert of Egypt and South-West Sinai," Geologische Rundschau, Vol. 83, No. 3, 1994, pp. 502-513. doi:10.1007/BF01083223

[14] M. Miller and T. Dixon, "Proterozoic Evolution of the Northern Part of the Hamisana Zone, Northeast Sudan: Constraints on Pan-African Accretionary Tectonics," Journal of the Geological Society of London, Vol. 149, 1992, pp. 743-750.

[15] M. G. Abdelsalam and R. J. Stern, "Sutures and Shear Zones in the Arabian Nubian Shield," Journal of African Earth Sciences, Vol. 23, No. 3, 1996, pp. 289-310. doi:10.1016/S0899-5362(97)00003-1

[16] M. G. Abdelsalam, "The Oko Shear Zone: Postaccretionary Deformations in the Arabian-Nubian Shield," Journal Geological Society London, Vol. 151, No. 5, 1994, pp. 767776. doi:10.1144/gsjgs. 151.5.0767

[17] H. Fritz, E. Wallbrecher, A. Khudeir, F. Abu El Ela and D. Dallmeyer, "Formation of Neoproterozoic Metamorphic Core Complexes during Oblique Convergence Eastern Desert, Egypt," Journal of African Earth Sciences, Vol. 23, No. 3, 1996, pp. 311-329. doi:10.1016/S0899-5362(97)00004-3

[18] R. J. Stern, "The Najd Fault System, Saudi Arabia and Egypt: A Late Precambrian Rift-Related Transform System," Tectonics, Vol. 4, No. 5, 1985, pp. 497-511. doi:10.1029/TC004i005p00497

[19] O. Greiling, M. Abdeen, A. Dardir, H. El Akhal, M. El Ramly, G. Kamal El Din, A. Osman, A. Rashwan, A. Rice and M. Sadek, "A Structural Synthesis of the Proterozoic Arabian-Nubian Shield in Egypt," Geologische Rundschau, Vol. 83, No. 3, 1994, pp. 484-501. doi:10.1007/BF01083222

[20] B. Blasband, S. White, P. Brooijmans, H. De Boorder and W. Visser, "Late Proterozoic Extensional Collapse in the Arabian-Nubian Shield," Journal of the Geological Society, Vol. 157, No. 3, 2000, pp. 615-628. doi:10.1144/jgs.157.3.615 
[21] R. A. Agar, "The Najd Fault System Revisited; a TwoWay Strike Slip Orogen in the Saudi Arabian Shield," Journal of Structural Geology, Vol. 9, No. 1, 1987, pp. 4148. doi:10.1016/0191-8141(87)90042-3

[22] M. Sultan, R. E. Arvidson, I. J. Duncan, R. J. Stern and B. Elkaliouby, "Extension of the Najd Shear System from Saudi-Arabia to the Central Eastern Desert of Egypt Based on Integrated Field and Landsat Observations," Tectonics, Vol. 7, No. 6, 1988, pp. 1291-1306. doi:10.1029/TC007i006p01291

[23] M. M. Abdeen and R. O. Greiling, "A Quantitative Structural Study of Late Pan-African Compressional Deformation in the Central Eastern Desert (Egypt) during Gondwana Assembly," Gondwana Research, Vol. 8, No. 4, 2005, pp. 457-471. doi:10.1016/S1342-937X(05)71148-5

[24] D. Avigad and Z. Gvirtzman, "Late Neoproterozoic Rise and Fall of the Northern Arabian-Nubian Shield: The Role of Lithospheric Mantle Delamination and Subsequent Thermal Subsidence," Tectonophysics, Vol. 477, No. 3-4, 2009, pp. 217-228. doi:10.1016/j.tecto.2009.04.018

[25] A. R. Moustafa, "Controls on the Development and Evolution of Transfer Zones: The Influence of Basement Structure and Sedimentary Thickness in the Suez Rift and Red Sea," Journal of Structural Geology, Vol. 19, No. 6, 1997, pp. 755-768. doi:10.1016/S0191-8141(97)00007-2

[26] M. Sultan, A. Yousef, S. Metwally, R. Becker, A. Milewski, W. Sauck, N. Sturchio, A. Mohamed, A. Wagdy, Z. El Alfy, D. Becker, Z. Sagintayev, M. El Sayed and B. Welton, "Red Sea Rifting Controls on Aquifer Distribution: Constraints from Geochemical, Geophysical, and Remote Sensing Data," Geological Society of America Bulletin, Vol. 123, No. 5-6, 2011, pp. 911-924. doi:10.1130/B30146.1

[27] A. Bojar, H. Fritz, S. Kargl and W. Unzog, "Phanerozoic Tectonothermal History of the Arabian Nubian Shield in the Eastern Desert of Egypt: Evidence from Fission Track and Paleostress Data," Journal of African Earth Sciences, Vol. 34, No. 1, 2002, pp. 191-202. doi:10.1016/S0899-5362(02)00018-0

[28] C. Montenat, P. D'estevou, B. Purser, P. Burollet, J. Jarrige, F. Sperber, E. Philobbos, J. Plaziat, P. Part, J. Richert, N. Roussel and J. Thiriet, "Tectonic and Sedimentary Evolution of the Gulf of Suez and the Northwestern Red Sea," Tectophysics, Vol. 153, No. 1-4, 1988, pp. 161-177. doi:10.1016/0040-1951(88)90013-3

[29] Z. Garfunkel, "Internal Structure of the Dead Sea Leaky Transform (Rift) in Relation to Plate Kinematics," Tectonophysics, Vol. 80, No. 1-4, 1981, pp. 81-108. doi:10.1016/0040-1951(81)90143-8

[30] R. S. Yeats, K. Sieh and C. R. Allen, "The Geology of Earthquakes," Oxford University Press, Oxford, 1997.

[31] Z. Garfunkel and Z. Ben-Avraham, "The Structure of the Dead Sea Basin," Tectonophysics, Vol. 266, No. 1-4, 1996, pp. 155-176. doi:10.1016/S0040-1951(96)00188-6

[32] A. C. Ries, R. M. Shackleton, R. H. Graham and W. R. Fitches, "Pan-African Structures, Ophiolites and Mélange in the Eastem Desert of Egypt: A Traverse at $26^{\circ} \mathrm{N}$," Journal of the Geological Society, Vol. 140, No. 1, 1983, pp. 75-95. doi:10.1144/gsjgs.140.1.0075
[33] S. El Gaby, F. K. List and R. Tehrani, "Geology, Evolution and Metallogenesis of the Pan-Afrcan Belt in Egypt," In: S. El Gaby and R. Greiling, Eds., The Pan-African Belt of NE Africa and Adjacent Areas, Tectonic Evolution and Economic Aspects, Braunschweig, 1988, pp. 17-68.

[34] M. F. El Ramly, R. O. Greiling, A. A. Rashwan and A. H. Ramsy, "Explanatory Note to Accompany the Geological and Structural Maps of Wadi Hafafit Area, Eastern Desert of Egypt," Annals Geological Survey of Egypt, Vol. 9, 1993, pp. 1-53.

[35] R. J. Stern, P. Johnson, A. Kröner and B. Yibas, "Neoproterozoic Ophiolites of the Arabian-Nubian Shield," In: T. M. Kusky, Ed., Precambrian Ophiolites and Related Rocks, Elsevier, Amsterdam, 2004, pp. 95-128. doi:10.1016/S0166-2635(04)13003-X

[36] B. Issawi, M. Francis, M. El Hinnawy, A. Mehanna and T. El Deftar, "Geology of the Safaga-Quseir Coastal Plain and of Mohamed Rabah Area," Annals Geological Survey of Egypt, Vol. 1, 1971, pp. 1-19.

[37] R. Said, "The Geology of Egypt," Balkema Publishers, Rotterdam, 1990.

[38] A. Al Sharhan, "Petroleum geology and Potential Hydrocarbon Plays in the Gulf of Suez Rift Basin, Egypt," AAPG Bulletin, Vol. 87, No. 1, 2003, pp. 143-180.

[39] A. R. Mustafa, "Controls on the Geometry of Transfer Zones in the Suez Rift and Northwest Red Sea: Implications for the Structural Geometry of Rift Systems," $A A P G$ Bulletin, Vol. 86, No. 6, 2002, pp. 979-1002.

[40] A. Agostini, G. Corti, A. Zeoli and G. Mulugeta, "Evolution, Pattern, and Partitioning of Deformation during Oblique Continental Rifting: Inferences from LithosphericScale Centrifuge Models," Geochemistry Geophysics Geosystems, Vol. 10, 2009, p. 23. doi:10.1029/2009GC002676

[41] S. Khalil and K. McClay, "Extensional Fault-Related Folding, Northwestern Red Sea, Egypt," Journal of Structural Geology, Vol. 24, No. 4, 2002, pp. 743-762. doi:10.1016/S0191-8141(01)00118-3

[42] W. Bosworth, "Geometry of Propagating Continental Rifts," Nature, Vol. 316, 1985, pp. 625-627. doi: $10.1038 / 316625 \mathrm{a} 0$

[43] J. Chorowicz and C. Sorlien, "Oblique Extensional Tectonics in the Malawi Rift Africa," Bulletin of the Geological Society of America, Vol. 104, No. 8, 1992, pp. 10151023.

doi:10.1130/0016-7606(1992)104<1015:OETITM>2.3.CO;2

[44] A. R. Moustafa and H. M. Khalil, "Superposed Deformation in the Northern Suez Rift, Egypt: Relevance to Hydrocarbons Exploration," Journal of Petroleum Geologists, Vol. 18, No. 3, 1995, pp. 245-266. doi:10.1111/j.1747-5457.1995.tb00905.x

[45] M. Steckler, F. Berthelot, N. Lyberis and X. Pichon, "Subsidence in the Gulf of Suez: Implications for Rifting and Plate Kinematics," Tectonophysics, Vol. 153, No. 1-4, 1988, pp. 249-270. doi:10.1016/0040-1951(88)90019-4

[46] N. Lyberis, "Tectonic Evolution of the Gulf of Suez and the Gulf of Aqaba," Tectonophysics, Vol. 153, No. 1-4, 1988, pp. 209-220. doi:10.1016/0040-1951(88)90016-9

[47] R. Reilinger, S. McClusky, M. Oral, R. King, M. Toksoz, 
A. Barka, I. Kinik, O. Lenk and I. Sanli, "Global Positioning System Measurements of Present-Day Crustal Movements in the Arabia-Africa-Eurasia Plate Collision Zone," Journal of Geophysical Research, Vol. 102, No. B5, 1997, pp. 9983-10000. doi:10.1029/96JB03736

[48] S. McClusky, R. Reilinger, S. Mahmoud, D. Ben Sari and A. Tealeb, "GPS Constraints of Africa (Nubia) and Arabia Plate Motions," Geophysical Journal International, Vol. 155, No. 1, 2003, pp. 126-138. doi:10.1046/j.1365-246X.2003.02023.x

[49] R. J. Stern and C. E. Gottfried, "Geochronologic and Isotopic Constraints on Late Precambrian Crustal Evolution in the Eastern Desert of Egypt," American Journal of Science, Vol. 285, No. 2, 1985, pp. 97-127. doi:10.2475/ajs.285.2.97
[50] E. M. Moussa, R. J. Stern, W. Manton and K. A. Ali, "SHRIMP Zircon Dating and Sm/Nd Isotopic Investigations of Neoproterozoic Granitoids, Eastern Desert, Egypt," Precambrian Research, Vol. 160, No. 3-4, 2008, pp. 341356. doi:10.1016/j.precamres.2007.08.006

[51] H. Eliwa, J. I. Kimura and T. Itaya, "Late Neoproterozoic Dokhan Volcanics, North Eastern Desert, Egypt: Geochemistry and Petrogenesis," Precambrian Research, Vol. 151, No. 1-2, 2006, pp. 31-52. doi:10.1016/i.precamres.2006.08.005

[52] A. El Sayed, R. Wahlstrom and O. Kulhanek, "Seismic Hazard of Egypt," Natural Hazard, Vol. 10, No. 3, 1994, pp. 247-259. doi:10.1007/BF00596145

[53] A. Badawy, "The Present Day Stress Field in Egypt," Annali Di Geofisical, Vol. 44, No. 3, 2001, pp. 557-570. 